Imperial College London
SUSTAINABLE

GAS

INSTITUTE
THE OXFORD

INSTITUTE

FOR ENERGY

STUDIES

October 2019

\title{
A mountain to climb?
}

\section{Tracking progress in scaling up} renewable gas production in Europe

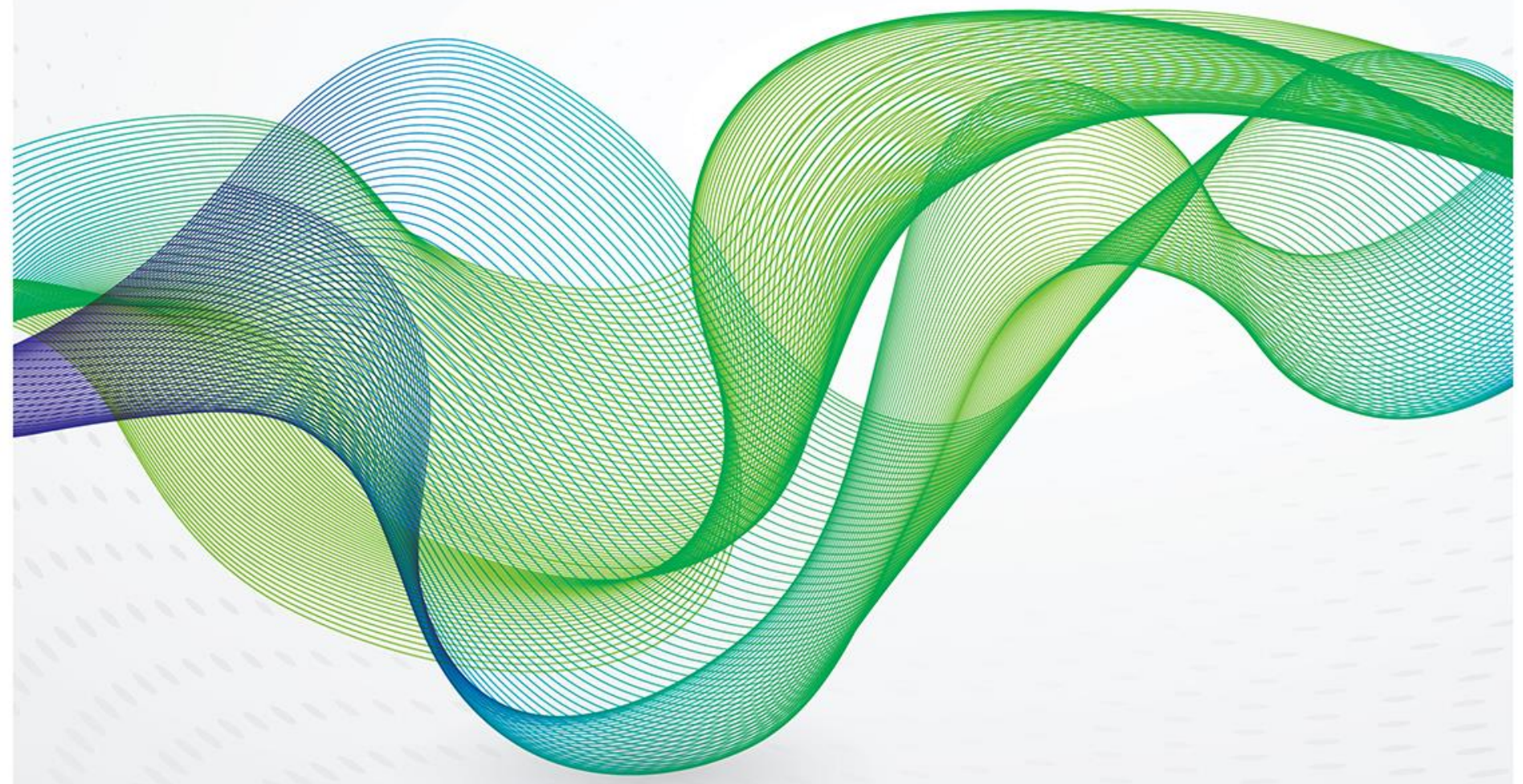



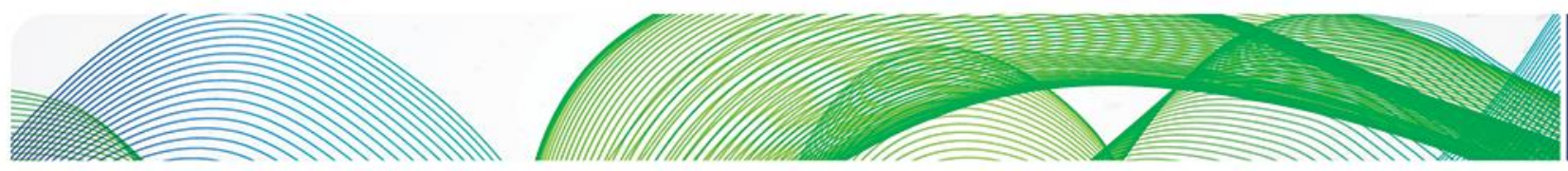

\section{잊조}

The contents of this paper are the author's sole responsibility. They do not necessarily represent the views of the Oxford Institute for Energy Studies or any of its members.

Copyright $\odot 2019$

Oxford Institute for Energy Studies \& Sustainable Gas Institute, Imperial College, London (Registered Charity, No. 286084)

This publication may be reproduced in part for educational or non-profit purposes without special permission from the copyright holder, provided acknowledgment of the source is made. No use of this publication may be made for resale or for any other commercial purpose whatsoever without prior permission in writing from the Oxford Institute for Energy Studies.

ISBN: 978-1-78467-147-1

DOI: https://doi.org/10.26889/9781784671471 

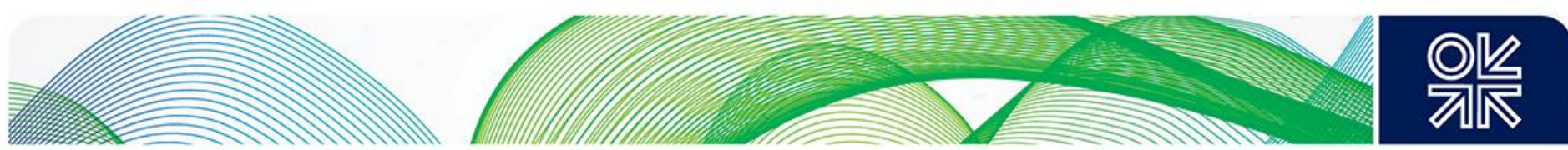

\section{Preface}

Over the past three years the Natural Gas Programme at OIES has published a number of papers on the future of gas, highlighting the need for the industry to demonstrate its ability to operate within a decarbonising energy system. This is particularly true in Europe, where policy makers have effectively signalled that gas may have a declining future beyond 2030 if it cannot play a role in meeting the EU's "net zero emissions by 2050" target. We have discussed how the gas industry might develop a narrative to meet this goal, and have described how bio-gas, bio-methane, hydrogen and synthetic gas can be part of the solution.

Having laid the conceptual and theoretical context, though, which essentially urged the industry to take active steps to show its "renewable gas" credentials, we have now decided to actively monitor what is actually happening in terms of practical activity. This report, which we have developed in cooperation with the Sustainable Gas Institute at Imperial College, shows our initial results in the form of a database of projects across the "low-carbon gas" space, and we intend to keep this updated over the coming months and years as a record of the progress that the industry is making. The report also reviews the range of targets that have been set for the potential share for renewable gas in the European energy mix by 2050 , and we will continue to assess the extent of industry activity relative to these goals. We would encourage any actors with information on additional projects to make contact with us, as we believe that the database could be a useful tool in discussions between industry players and policy makers. We will also be extending the database to cover projects across the globe, as we believe that the current initiatives in Europe could well provide a catalyst for action elsewhere.

Finally, we would like to thank the Sustainable Gas Institute, and especially Gbemi Oluleye and Adam Hawkes, for their input to this report, and we look forward to continuing our cooperation with them.

\section{James Henderson}

Director, Natural Gas Programme

Oxford Institute for Energy Studies 

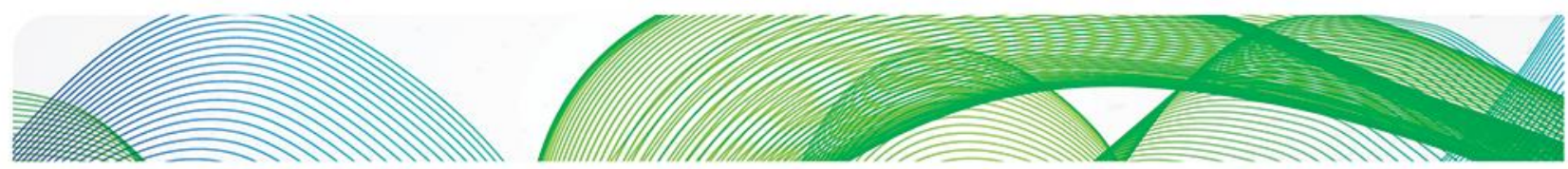
이잦

\section{Contents}

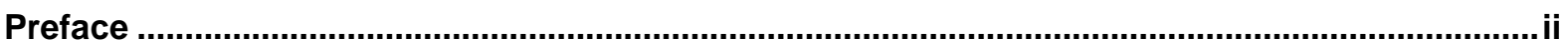

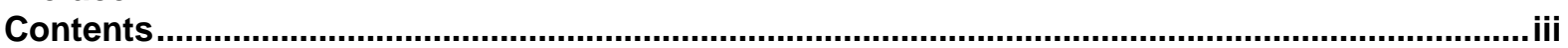

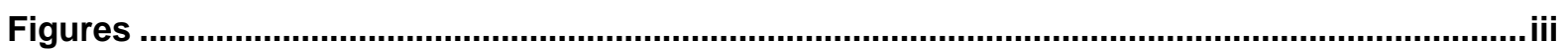

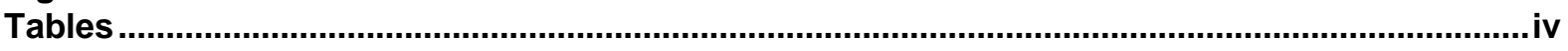

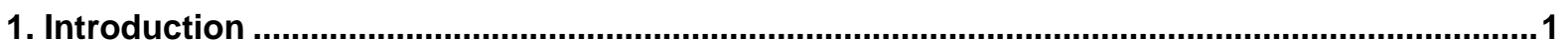

2. Long term targets and implied development pathways......................................................

2.1 European Commission: A Clean Planet for all (Nov 2018) ................................................... 3

2.2 Entsog/Enstoe: Ten Year Network Development Plan (2018)............................................... 4

2.3 Navigant: Gas for Climate. The optimal role for gas in a net-zero emissions energy system ...... 5

2.4 Comparison of renewable gas production levels envisaged in these studies .............................. 6

3. Renewable gas (biomethane, renewable methane and hydrogen) database ............................8

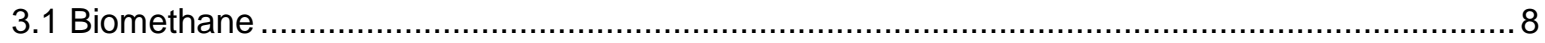

3.2 Renewable hydrogen and renewable methane (other than biomethane) ................................12

4. Current costs and potential cost-reduction pathway if scale up progresses in line with target

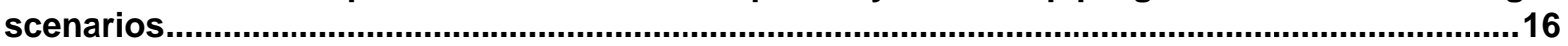

5. Benchmarking cost reduction estimates for intended development pathways .......................19

6. Conclusion: what more is required to be on track for each scenario? ..................................22

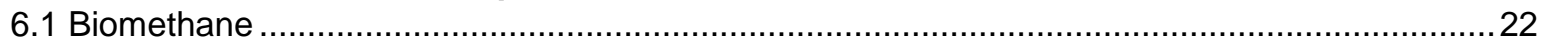

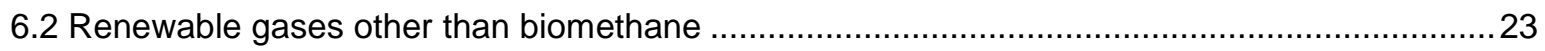

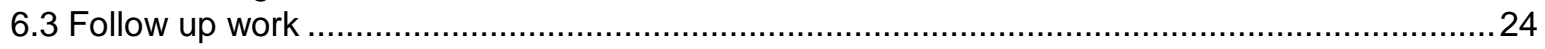

Appendix. List of names and locations of plants/projects included in SGI/OIES database .......25

\section{Figures}

Figure 1: EU projections of 2050 consumption of gaseous fuels converted to TWh ............................

Figure 2: Total Europe biomethane production under ENTSOG scenarios ….................................

Figure 3: Navigant report: 2050 production volumes and cost projections ........................................... 6

Figure 4: Per cent per annum average annual scale up by scenario ...............................................

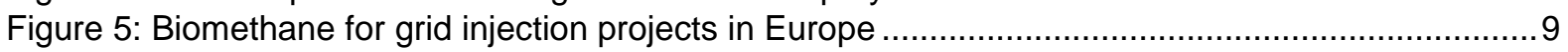

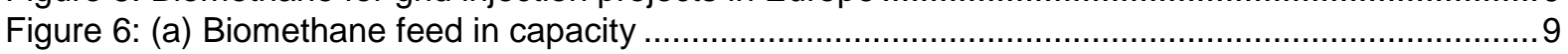

Figure 6: (b) Associated number of plants (the average capacity growth is $6.88 \%$, the max is $21 \%$

and minimum 1.2\%) ............................................................................................................ 10

Figure 7: Contribution from each upgrading technology, and relative share of the total current EU feed

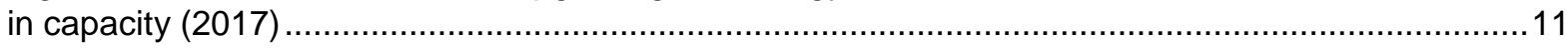

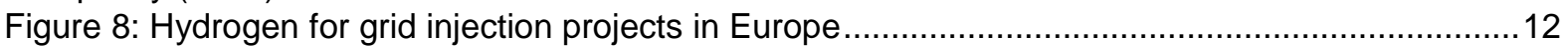

Figure 9: Renewable methane for grid injection projects in Europe ............................................13

Figure 10: Status of Hydrogen and renewable methane for grid injection projects in Europe (2019) ..14

Figure 11: Unit project cost. The unit project cost is the ratio of the total project budget and the

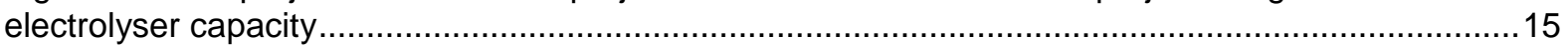

Figure 12: Renewable gas production costs in 2018, and projections for 2030 and $2050 \ldots \ldots \ldots \ldots \ldots . . . . .17$

Figure 13: Production costs for biomethane based on anaerobic digestion .....................................18

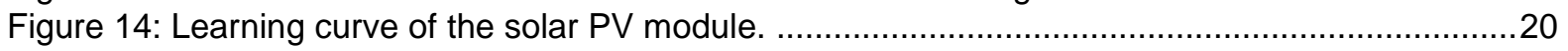

Figure 15: Estimates of plausible future learning rate ranges for several important electricity

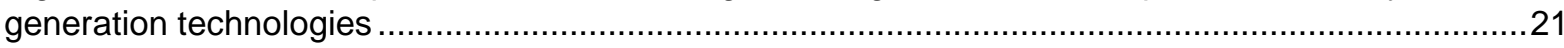

Figure 16: Projections of future biomethane production under various scenarios compared with current production . 

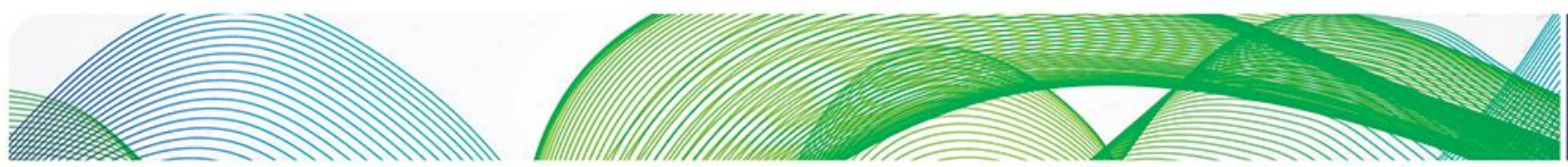

\section{임}

\section{Tables}

Table 1: EU Clean Planet for all scenarios 3

Table 2: Total Europe Power to Gas production under ENTSOG scenarios ....................................

Table 3: Total Europe production in 2030 and 2050 under selected scenarios (TWh) ....................... 7

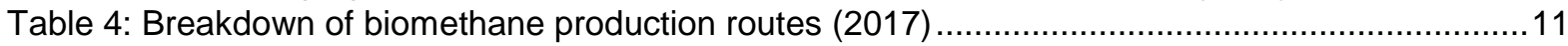

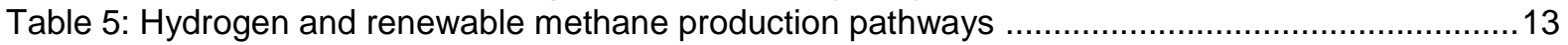

Table 6: Associated hydrogen output capacity for projects (status in 2019) .....................................15 

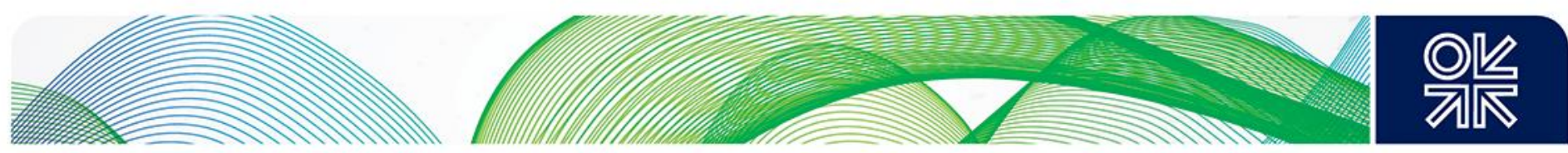

\section{Introduction}

In recent years, and particularly following agreement of specific goals at the COP21 meeting in Paris in December 2015, the global energy industry has increased its focus on decarbonisation. Against this background, both the Natural Gas Programme at OIES and the Sustainable Gas Institute at Imperial College have been conducting research relating to the future of the gas industry in a decarbonising energy system. ${ }^{1}$

Prior to 2015, many incumbent players in the gas industry had advocated that, since natural gas has the lowest carbon dioxide emissions among fossil fuels, it would have a role to play in a low carbon energy system, and reassurance was given that there were enough natural gas reserves to last for over 200 years. $^{2}$ As the implications of the Paris Agreement became clearer, it was realised that to be consistent with the objective of keeping global temperature rise 'well below' $2^{\circ} \mathrm{C}$, the energy system should be approaching carbon neutrality by 2050 . Continuing to burn significant quantities of fossil-derived natural gas would not be consistent with the Paris Agreement.

The power generation sector has made the greatest progress in decarbonisation up to now. While actual implementation varies by country, there is a clear path forward to reduce carbon emissions from generation of electricity. After several years of subsidies, the cost of wind and photovoltaic generation has now fallen to a level where, in many situations, it is able to compete with natural gas and other fossil fuel alternatives without any government support. ${ }^{3}$ Renewables (wind, solar, biomass) achieved a one per cent share of global primary energy supply in 2006, and by 2018 this had risen to around five per cent. ${ }^{4}$ This rapid growth has led to some suggestions that the decarbonised energy system would be dominated by electricity, across all sectors, including transport, industry and buildings/heat. Several studies, however, have considered the feasibility and cost of various 'all electric' decarbonisation solutions in comparison with alternative 'hybrid' solutions where gaseous fuel continues to play a significant role in the energy system. ${ }^{5}$ The consistent message from such studies has been that continuing to use existing gas infrastructure for energy storage and transmission provides a much lower cost pathway to decarbonisation than the 'all electric' alternative. However, it is also understood that gas used in such a hybrid solution will need to be decarbonised.

A number of studies have developed detailed scenarios for production of various types of renewable or low carbon gas (biomethane from anaerobic digestion, synthetic gas from gasification of biomass, power to hydrogen, power to methane or hydrogen from methane reforming with carbon captura and storage (CCS)). Specifically:

\footnotetext{
See for example: Spiers, J. et al, (July 2017). SGI. http://www.sustainablegasinstitute.org/a-greener-gas-grid/

Stern, J. (December 2017). OIES. https://www.oxfordenergy.org/wpcms/wp-content/uploads/2017/12/Challenges-to-the-Futureof-Gas-unburnable-or-unaffordable-NG-125.pdf

Lambert, M. (October 2018). OIES. https://www.oxfordenergy.org/wpcms/wp-content/uploads/2018/10/Power-to-Gas-LinkingElectricity-and-Gas-in-a-Decarbonising-World-Insight-39.pdf

Stern, J. (February 2019). OIES. https://www.oxfordenergy.org/wpcms/wp-content/uploads/2019/02/Narratives-for-NaturalGas-in-a-Decarbonisinf-European-Energy-Market-NG141.pdf

${ }^{2}$ See, for example, Shell Sustainability Report 2013: https://reports.shell.com/sustainability-report/2013/our-activities/naturalgas.html

${ }^{3}$ www.Ise.ac.uk/Grantham/nstitute/faqs/do-renewable-energy-technologies-need-government-subsidies/

4 BP Energy Outlook 2019 edition.

${ }^{5}$ See, for example, Poyry, (May 2018).

https://www.poyry.com/sites/default/files/media/related material/poyrypointofview fullydecarbonisingeuropesenergysystemby2 050.pdf

DENA, (October 2018).

https://www.dena.de/fileadmin/dena/Dokumente/Pdf/9283_dena_Study_Integrated_Energy_Transition.PDF
} 

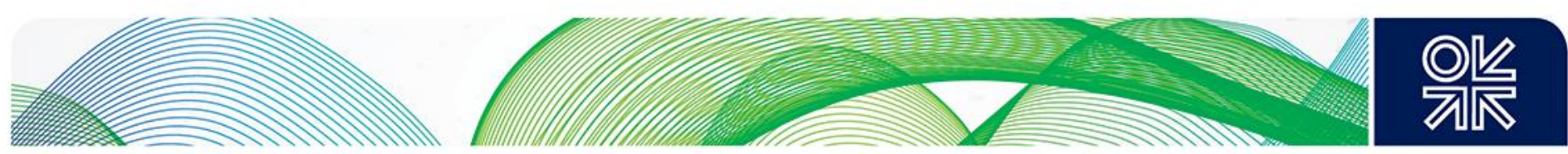

- in November 2018, the European Commission published 'A Clean Planet for All - A European strategic long-term vision for a prosperous, modern, competitive and climate neutral economy'. ${ }^{6}$ This report contained multiple scenarios for consumption of renewable gaseous fuels in 2050.

- in December 2018, the European Network of Transmission System Operators for Gas and Electricity (Entsog and Entoe) published their final scenario report for the 10 year network development plan, ${ }^{7}$ which included forecasts for renewable gas production in 2030 and 2040.

- in March 2019, the 'Gas for Climate' group of leading European Transmission System operators published a report developed by Navigant on 'The optimal role for gas in a net-zero emissions energy system'. 8 This report also contained scenarios for renewable gas production in 2050.

More details on the ambitious targets set by these studies are given in Section 2, together with our analysis of the scale up pathways which would be implied by such target scenarios.

Note that throughout this report, in the absence of agreed industry definitions, we refer to 'renewable gas' and 'low-carbon gas' to cover the various alternatives for gaseous fuels (either hydrogen or methane) which may be used in future as significantly lower carbon alternatives to fossil-derived natural gas. Many of these are not zero-carbon, particularly where the electricity used is not 100 per cent renewable, or carbon is not fully captured and stored, but they are relevant as they are steps on the pathway to eventual decarbonisation of the energy system.

SGI and OIES have been working together, with input from a range of sources and stakeholders, to build a database of current production of renewable gas, and the status of projects under development. Our objective has been to assess the extent to which specific actions being taken, principally by governments, regulators and industry investors, are consistent with being on a pathway which could reasonably be expected to reach the ambitious targets being contemplated by reports such as those listed above. We have focussed on Europe initially, which has been taking the lead on renewable gas developments, but we intend future updates to expand the scope beyond Europe.

Our concern is that while it is relatively easy to write a report with bold projections 30 years ahead, there are significant barriers to overcome if those bold projections are to be realised:

- the scale of the energy system is so large in relation to the small scale of current pilot and demonstration projects for production of renewable gas;

- there is an expectation that as levels of production increase, there will be a significant reduction in costs, but there is not yet sufficient evidence that such cost reductions are achievable;

- development of new infrastructure projects has a long lead time: a project at the feasibility study stage in 2019 is likely to be onstream around 2023 at the earliest, and more likely somewhat later;

- in the absence of greater government and regulatory certainty, it will be difficult for potential project developers to justify investing shareholder capital or raise third party finance to build the large scale plants which will be required to meet the projected production levels.

This report examines these issues in more detail.

\footnotetext{
${ }^{6} \mathrm{https}: / /$ eur-lex.europa.eu/legal-content/EN/TXT/PDF/?uri=CELEX:52018DC0773\&from=EN

7 https://www.entsog.eu/sites/default/files/entsogmigration/publications/TYNDP/2018/entsos tyndp 2018 Final Scenario Report.pdf

${ }^{8}$ https://www.gasforclimate2050.eu/files/files/Navigant Gas for Climate The optimal role for gas in a net zero emissions energy system March 2019.pdf
} 

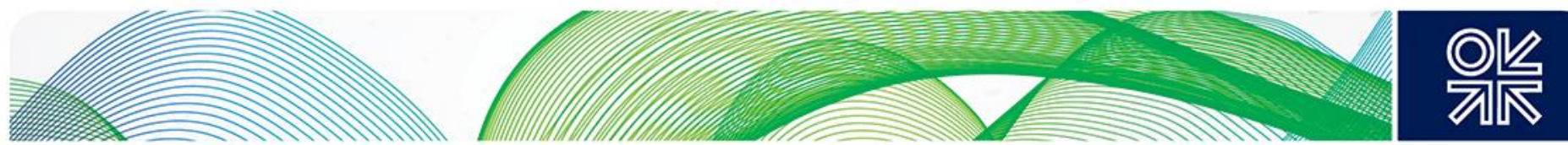

\section{Long term targets and implied development pathways}

In recent months, several reports have been published making bold projections on the level of renewable gas production which could be achieved in Europe by 2040 or 2050 . For this report, we have selected three of these reports for further analysis. These have been chosen as they have been produced with backing of key players in the European gas industry.

\subsection{European Commission: A Clean Planet for all (Nov 2018)}

This report, ${ }^{9}$ subtitled 'A European strategic long-term vision for a prosperous, modern, competitive and climate neutral economy' was published in November 2018, together with a more detailed document 'In-Depth Analysis in support of the Commission Communication COM(2018) 773'.10 The latter document contains details of eight scenarios for 2050, all of which would achieve a more than 80 per cent reduction in greenhouse gas (GHG) emissions compared to the 1990 baseline. The key features of each scenario are given in Table 1 (taken from the EU report). ${ }^{11}$

Table 1: EU Clean Planet for all scenarios

\section{Long Term Strategy Options}

\begin{tabular}{|c|c|c|c|c|c|c|c|c|}
\hline & $\begin{array}{c}\text { Electrification } \\
\text { (ELEC) }\end{array}$ & $\begin{array}{l}\text { Hydrogen } \\
\text { (H2) }\end{array}$ & $\begin{array}{l}\text { Power-to-X } \\
\text { (P2X) }\end{array}$ & $\begin{array}{l}\text { Energy } \\
\text { Efficiency } \\
\text { (EE) }\end{array}$ & $\begin{array}{l}\text { Circular } \\
\text { Economy } \\
\text { (CIRC) }\end{array}$ & $\begin{array}{c}\text { Combination } \\
\text { (COMBO) }\end{array}$ & $\begin{array}{c}1.5^{\circ} \mathrm{C} \\
\text { Technical } \\
(1.5 \mathrm{TECH})\end{array}$ & $\begin{array}{c}1.5^{\prime} \mathrm{C} \text { Sustainable } \\
\text { Lifestyles } \\
\text { (1.5LIFE) }\end{array}$ \\
\hline Main Drivers & $\begin{array}{c}\text { Electrification in } \\
\text { all sectors }\end{array}$ & $\begin{array}{l}\text { Hydrogen in } \\
\text { industry, } \\
\text { transport and } \\
\text { buildings }\end{array}$ & $\begin{array}{l}\text { E-fuels in } \\
\text { industry, } \\
\text { transport and } \\
\text { buildings }\end{array}$ & $\begin{array}{l}\text { Pursuing deep } \\
\text { energy efficiency } \\
\text { in all sectors }\end{array}$ & $\begin{array}{l}\text { Increased } \\
\text { resource and } \\
\text { material } \\
\text { efficiency }\end{array}$ & $\begin{array}{l}\text { Cost-efficient } \\
\text { combination of } \\
\text { options from } 2^{\circ} \mathrm{C} \\
\text { scenarios }\end{array}$ & $\begin{array}{c}\text { Based on } \\
\text { COMBO with } \\
\text { more BECCS, CCS }\end{array}$ & $\begin{array}{c}\text { Based on } \\
\text { COMBO and } \\
\text { CIRC with } \\
\text { lifestyle changes }\end{array}$ \\
\hline $\begin{array}{l}\text { GHG target } \\
\text { in } 2050\end{array}$ & \multicolumn{5}{|c|}{$\begin{array}{l}-80 \% \text { GHG (excluding sinks) } \\
\text { ["well below } 2^{\circ} \mathrm{C} \text { " ambition] }\end{array}$} & $\begin{array}{l}-90 \% \text { GHG (incl. } \\
\text { sinks) }\end{array}$ & \multicolumn{2}{|c|}{$\begin{array}{l}-100 \% \text { GHG (incl. sinks) } \\
\text { ["1.5 } 5^{\circ} \text { " ambition] }\end{array}$} \\
\hline $\begin{array}{l}\text { Major Common } \\
\text { Assumptions }\end{array}$ & \multicolumn{4}{|c|}{$\begin{array}{l}\text { - Higher energy efficiency post } 2030 \\
\text { - Deployment of sustainable, advanced biofuels } \\
\text { - Moderate circular economy measures } \\
\text { - Digitilisation }\end{array}$} & \multicolumn{4}{|c|}{$\begin{array}{l}\text { - Market coordination for infrastructure deployment } \\
\text { - BECCS present only post- } 2050 \text { in } 2^{\circ} \mathrm{C} \text { scenarios } \\
\text { - Significant learning by doing for low carbon technologies } \\
\text { - Significant improvements in the efficiency of the transport system. }\end{array}$} \\
\hline Power sector & \multicolumn{8}{|c|}{$\begin{array}{l}\text { Power is nearly decarbonised by 2050. Strong penetration of RES facilitated by system optimization } \\
\text { (demand-side response, storage, interconnections, role of prosumers). Nuclear still plays a role in the power sector and CCS deployment faces limitations. }\end{array}$} \\
\hline Industry & $\begin{array}{c}\text { Electrification of } \\
\text { processes }\end{array}$ & $\begin{array}{l}\text { Use of } \mathrm{H} 2 \text { in } \\
\text { targeted } \\
\text { applications }\end{array}$ & $\begin{array}{l}\text { Use of e-gas in } \\
\text { targeted } \\
\text { applications }\end{array}$ & $\begin{array}{l}\text { Reducing energy } \\
\text { demand via } \\
\text { Energy Efficiency }\end{array}$ & $\begin{array}{l}\text { Higher recycling } \\
\text { rates, material } \\
\text { substitution, } \\
\text { circular measures }\end{array}$ & \multirow{3}{*}{$\begin{array}{l}\text { Combination of } \\
\text { most Cost- } \\
\text { efficient options } \\
\text { from "well below } \\
2^{\circ} \mathrm{C} \text { "scenarios } \\
\text { with targeted } \\
\text { application } \\
\text { (excluding CIRC) }\end{array}$} & \multirow{3}{*}{$\begin{array}{l}\text { COMBO but } \\
\text { stronger }\end{array}$} & $\begin{array}{l}\mathrm{CIRC}+\mathrm{COMBO} \\
\text { but stronger }\end{array}$ \\
\hline Buildings & $\begin{array}{l}\text { Increased } \\
\text { deployment of } \\
\text { heat pumps }\end{array}$ & $\begin{array}{l}\text { Deployment of } \\
\mathrm{H} 2 \text { for heating }\end{array}$ & $\begin{array}{l}\text { Deployment of } \\
\text { e-gas for heating }\end{array}$ & $\begin{array}{l}\text { Increased } \\
\text { renovation rates } \\
\text { and depth }\end{array}$ & $\begin{array}{l}\text { Sustainable } \\
\text { buildings }\end{array}$ & & & $\begin{array}{l}\mathrm{CIRC}+\mathrm{COMBO} \\
\text { but stronger }\end{array}$ \\
\hline Transport sector & $\begin{array}{l}\text { Faster } \\
\text { electrification for } \\
\text { all transport } \\
\text { modes }\end{array}$ & $\begin{array}{l}\text { H2 deployment } \\
\text { for HDVs and } \\
\text { some for LDVs }\end{array}$ & $\begin{array}{l}\text { E-fuels } \\
\text { deployment for } \\
\text { all modes }\end{array}$ & $\begin{array}{l}\text { Increased } \\
\text { modal shift }\end{array}$ & $\begin{array}{l}\text { Mobility as a } \\
\text { service }\end{array}$ & & & $\begin{array}{l}\text { - } \mathrm{CIRC}+\mathrm{COMBO} \\
\text { but stronger } \\
\text { - Alternatives to } \\
\text { air travel }\end{array}$ \\
\hline Other Drivers & & $\begin{array}{c}\mathrm{H} 2 \text { in gas } \\
\text { distribution grid }\end{array}$ & $\begin{array}{c}\text { E-gas in gas } \\
\text { distribution grid }\end{array}$ & & & & $\begin{array}{l}\text { Limited } \\
\text { enhancement } \\
\text { natural sink }\end{array}$ & $\begin{array}{l}\text { - Dietary changes } \\
\text { - Enhancement } \\
\text { natural sink }\end{array}$ \\
\hline
\end{tabular}

Source: EU Clean Planet for All, supporting analysis

\footnotetext{
${ }^{9}$ https://eur-lex.europa.eu/legal-content/EN/TXT/PDF/?uri=CELEX:52018DC0773\&from=EN

${ }^{10}$ https://ec.europa.eu/clima/sites/clima/files/docs/pages/com 2018733 analysis in support en 0.pdf

Table 1, Page 56 in EU Clean Planet for All, supporting analysis (link at Footnote 10).
} 

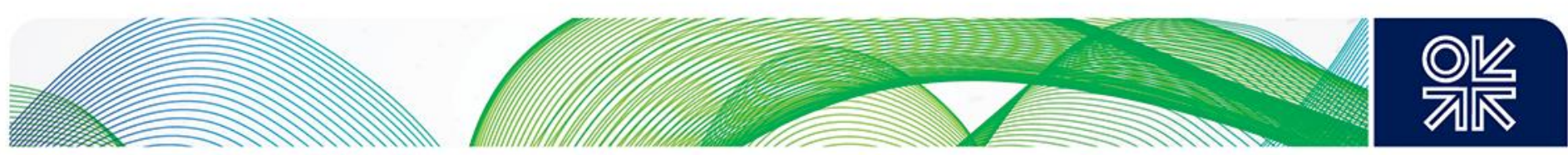

All scenarios are intended to achieve the EU target of 80 per cent reduction in GHG emissions by 2050, while the last three aim for a more ambitious 90 per cent and 100 per cent reduction of emissions. All the scenarios have the power sector being nearly fully decarbonised by 2050 , so the main differences between scenarios relate to the assumptions regarding energy use in the industry, buildings and transport sectors. In particular, the 'Hydrogen ( $\mathrm{H} 2)^{\prime}$ 'scenario assumes a large penetration of hydrogen in those three sectors, while 'Power-to-X (P2X)' assumes use of 'e-gas' (renewable methane) in industry and buildings and 'e-fuels' (liquid and gaseous fuels derived from renewable power).

The report then goes on to give detailed data for the consumption of natural gas, biogas (both biogas and biomethane), gas from waste, e-gas and hydrogen in the various scenarios.

The total consumption of gaseous fuels in the report is summarised in Figure 1. For ease of reference and consistency with other data in this paper, we have converted the data to TWh. (Note that Bcm of natural gas equivalent can be obtained by dividing TWh by a factor of approximately 10.4).

\section{Figure 1: EU projections of 2050 consumption of gaseous fuels converted to TWh}

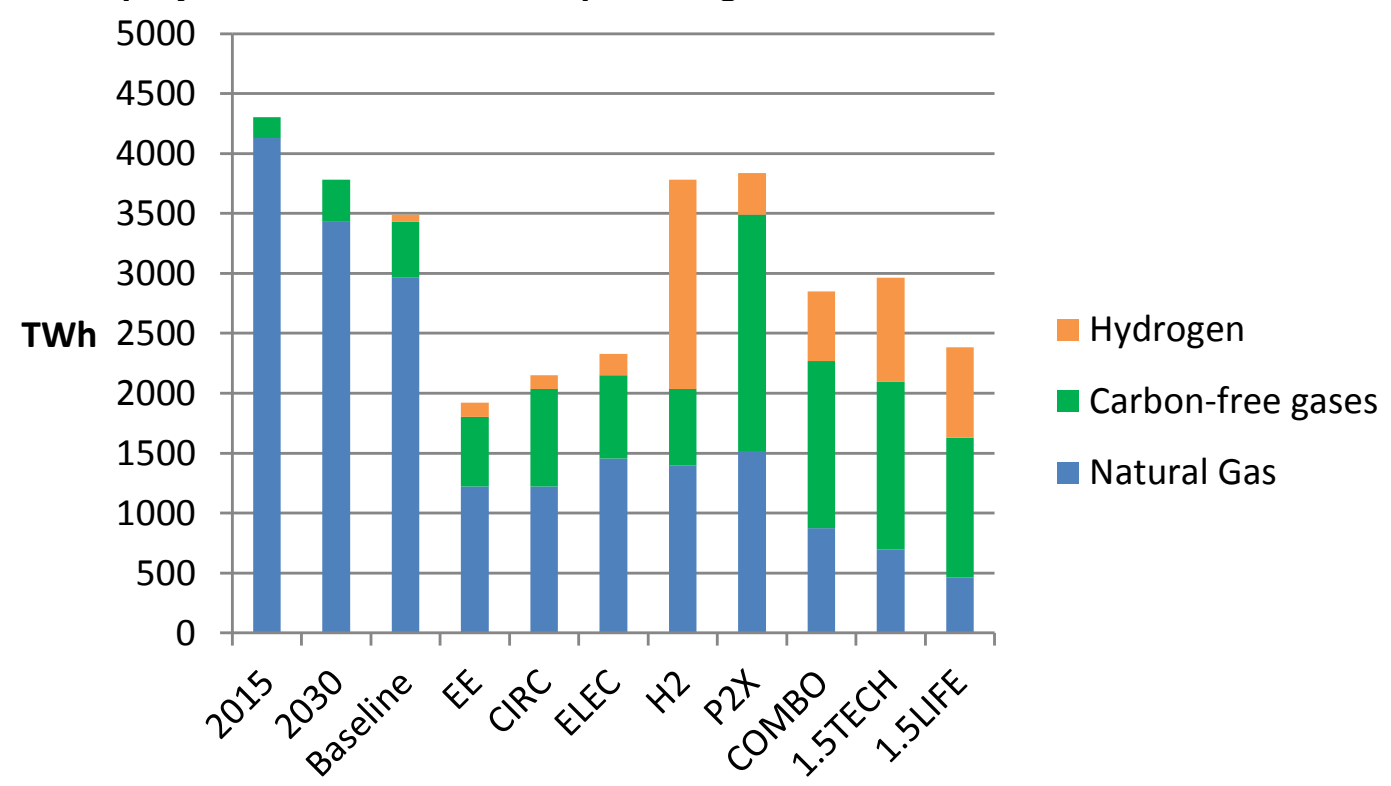

Source: EU Clean Planet for all, supporting analysis, Figure 33, and authors' calculations

For the analysis of required rates of scale up in the remainder of this paper, we have selected the $\mathrm{H} 2$, P2X and Combo scenarios, since these call for the largest quantities of carbon-free gases by 2050. Note that all scenarios show natural gas (the fossil fuel) consumption at one third or less of its 2015 level. The H2 and P2X scenarios envisage total demand for gaseous fuels in 2050 being of a similar order of magnitude to current levels (in the range 3500 to $4500 \mathrm{TWh}$ per year), but requiring over 2000 TWh of renewable gas, compared with less than 50 TWh of renewable gas production today.

\subsection{Entsog/Enstoe: Ten Year Network Development Plan (2018)}

Every two years the European Network of Transmission System Operators for Gas (ENTSOG), and its sister organisation for electricity, ENTSOE, are required by the European regulator to issue a Ten Year Network Development Plan (TYNDP). The latest TYNDP was produced in 2018, with the Final Scenario report containing details of possible European energy futures up to 2040 being released in December 2018. ${ }^{12}$ This report covers three scenarios: Sustainable Transition, Global Climate Action

${ }^{12}$ https://www.entsog.eu/sites/default/files/entsogmigration/publications/TYNDP/2018/entsos tyndp 2018 Final Scenario Report.pdf 

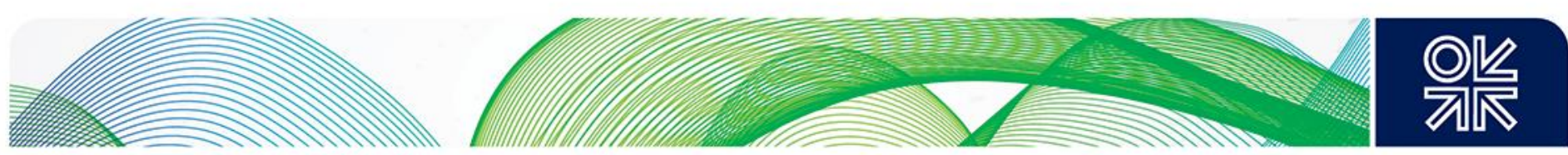

(GCA) and Distributed Generation (DG). Of the three, the first is not assessed to be on track to meet the EU 2050 decarbonisation target, but the last two are. For that reason, this paper focuses on the GCA and DG scenarios. As supporting documentation, the TYNDP also contains detailed spreadsheets with volumes of biomethane on an annual basis up to 2040 and snapshots for Power-to Gas (P2G) in 2030 and 2040.

The levels of biomethane production under each scenario are shown in Figure 2, and the levels of total European P2G production (either hydrogen or synthetic methane, blended into the gas grid) under the GCA and DG scenarios are given in Table 2.

\section{Source: ENTSOG TYNDP 2018}

Table 2: Total Europe Power to Gas production under ENTSOG scenarios

\begin{tabular}{|l|c|c|}
\hline TWh & 2030 & 2040 \\
\hline Global Climate Action & 13.91 & 95.06 \\
\hline Distributed Generation & 5.92 & 47.79 \\
\hline
\end{tabular}

Source: ENTSOG TYNDP 2018

Figure 2: Total Europe biomethane production under ENTSOG scenarios

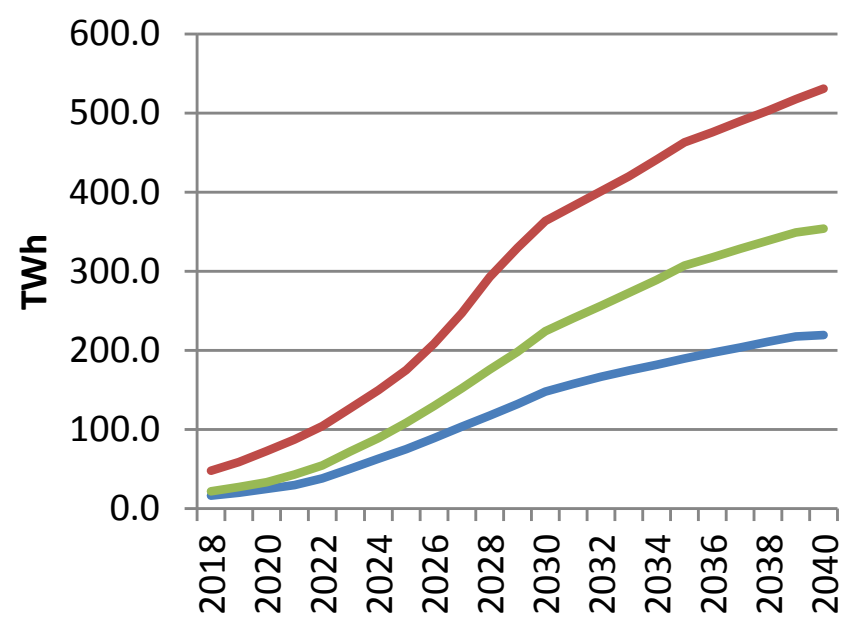

Sustainable Transition

Distributed Generation

Global Climate Action

Source: ENTSOG TYNDP 2018

Table 2: Total Europe Power to Gas production under ENTSOG scenarios

\begin{tabular}{|l|c|c|}
\hline TWh & 2030 & 2040 \\
\hline Global Climate Action & 13.91 & 95.06 \\
\hline Distributed Generation & 5.92 & 47.79 \\
\hline
\end{tabular}

Source: ENTSOG TYNDP 2018

\subsection{Navigant: Gas for Climate. The optimal role for gas in a net-zero emissions energy system}

A group of seven European gas transport companies (Enagás, Fluxys, Gasunie, GRTgaz, Open Grid Europe, Snam and Teréga), plus the European and Italian biogas associations, have together formed the 'Gas for Climate: a path to 2050' group. ${ }^{13}$ The group contracted the consultants, Ecofys, to produce an initial report published in March 2018. ${ }^{14}$ The same consultants, rebranded as Navigant, produced a more comprehensive updated report which was published in March 2019. ${ }^{15}$

${ }^{13} \mathrm{https}: / /$ www.gasforclimate2050.eu/who-we-are

${ }_{14}$ https://gasforclimate2050.eu/files/files/Ecofys Gas for Climate Report Study March18.pdf 

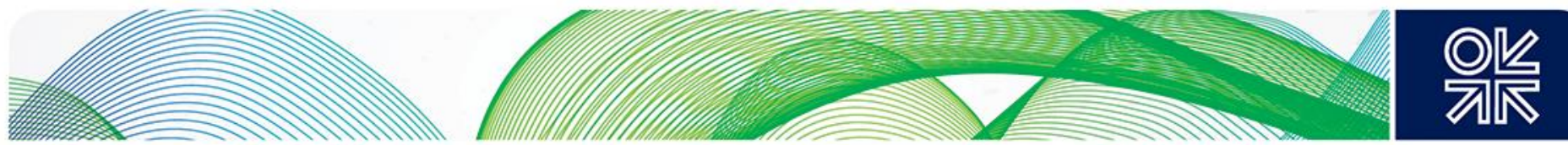

The report compared two pathways, 'minimal gas' (where electricity dominated the path to decarbonisation) and 'optimised gas' (which envisaged continued use of gas infrastructure) both of which would arrive at a net-zero emissions EU energy system by 2050 . It concluded that the 'optimised gas' scenario would save society $€ 217$ billion annually by 2050 compared with the 'minimal gas scenario'. The levels of renewable gas production required by the optimal gas scenario by 2050 total 1170 TWh of renewable methane and 1710 TWh of renewable hydrogen. The split of that volume across different pathways and the projected unit production costs are shown in Source:.

It should be noted that for 'green' hydrogen production (manufactured via electrolysis using renewable electricity), the study assessed that, in 2050, only about 200 TWh would be produced using surplus electricity production resulting from fluctuations in grid demand, with over 1,500 TWh being produced using dedicated renewable electricity generation (offshore wind farms or solar farms specifically built to provide electricity for electrolysis).

Figure 3: Navigant report: 2050 production volumes and cost projections

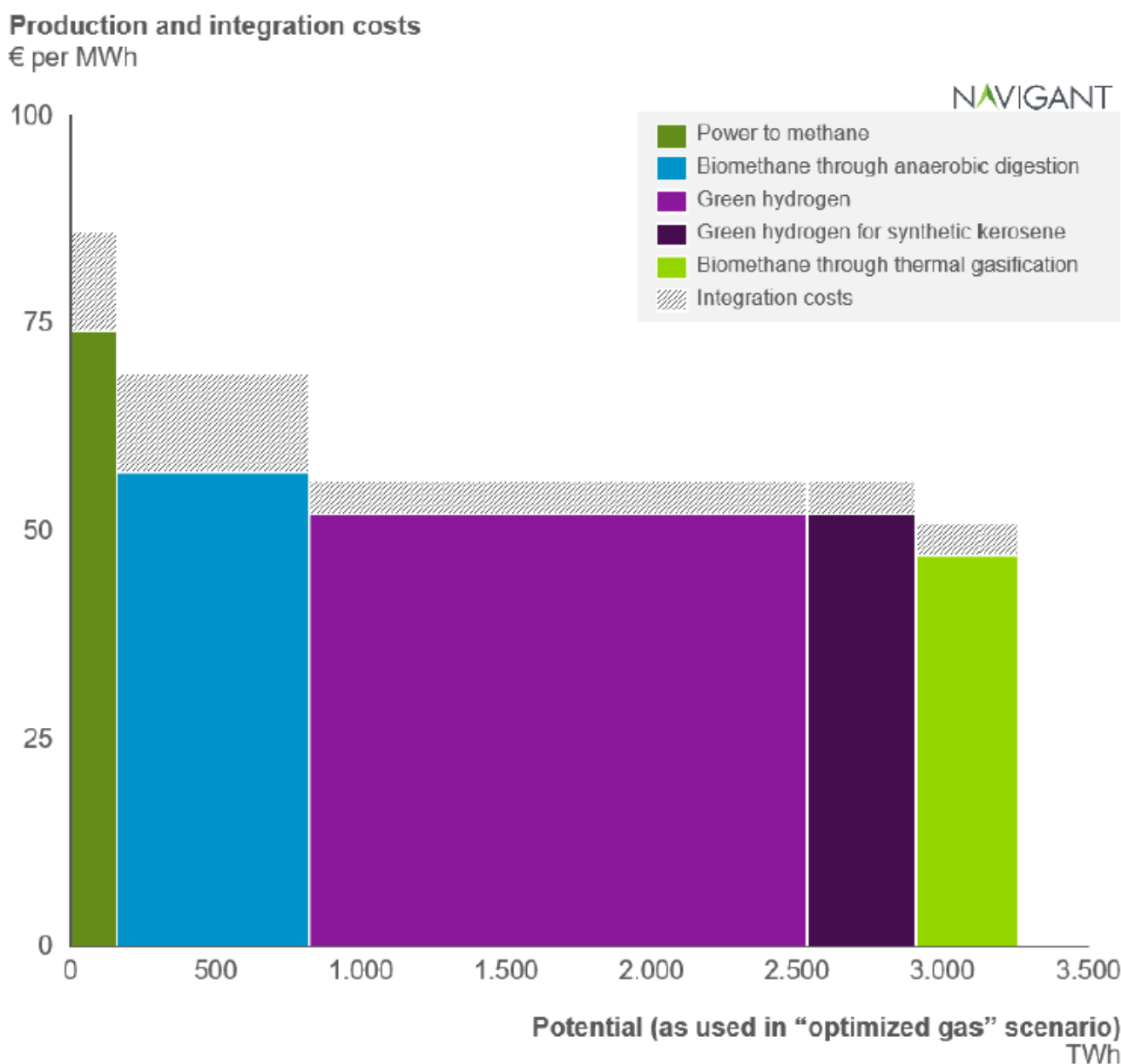

Source: Navigant, Gas for Climate March 2019

\subsection{Comparison of renewable gas production levels envisaged in these studies}

The current (2019) level of renewable gas production is small. While consistent, reliable and up to date data is not readily available, total EU biomethane production for grid injection is estimated to be around $20 \mathrm{TWh}^{16}$ and current power to methane and green hydrogen production is negligible.

\footnotetext{
${ }^{16}$ According to EBA Statistical review 2018, total biomethane production in 2017 was 19.4 TWh.
} 

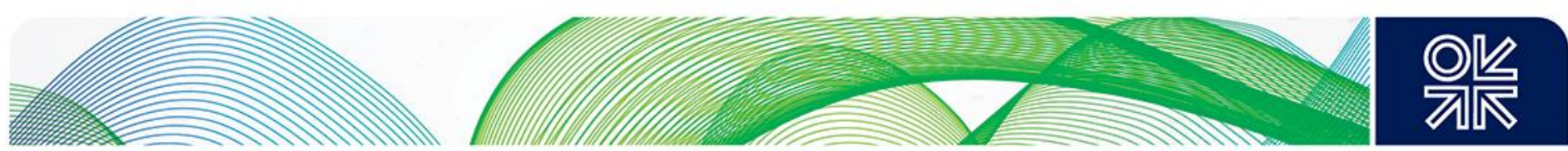

Table 3: Total Europe production in 2030 and 2050 under selected scenarios (TWh)

\begin{tabular}{|l|c|c|}
\hline TWh & $\mathbf{2 0 3 0}$ & $\mathbf{2 0 5 0}$ \\
\hline Navigant Opt Gas Power to Methane & & 160 \\
\hline EUCP4A Combo Power to Methane & & 581 \\
\hline EUCP4A P2X Power to Methane & 14 & 1047 \\
\hline ENTSOG GCA Power to Methane & & \\
\hline & & 660 \\
\hline Navigant Opt Gas Biomethane & 349 & 814 \\
\hline EUCP4A Combo Biomethane & 349 & 930 \\
\hline EUCP4A Combo Biomethane & 224 & \\
\hline ENTSOG GCA Biomethane & & \\
\hline
\end{tabular}

Source: Authors' analysis of stated sources

Table 3 summarises the 2030 and 2050 targets under selected scenarios, and Figure 4 shows the calculated annual average percentage increase in renewable gas production which is contemplated by the various scenarios described above. It can be seen that the required level of scale up, in some cases requires well over 20 per cent per annum increases sustained over many years. This is likely to be challenging to achieve.

Some comfort can perhaps be drawn from looking at the rate of increase of solar and wind power generation over the 10 year period from 2007 to $2017 .{ }^{17}$ Over that period, total EU solar power generation increased from 3.8 TWh to 119.7 TWh, an average annual increase of 41 per cent. At the same time, total EU wind power generation increased from 104.4 TWh to $362.2 \mathrm{TWh}$, an average annual increase of 13.2 per cent.

These historic increases in renewable power generation are clearly significant, but were achieved with the help of strongly supportive government policy, for example feed-in tariffs and other subsidies for renewable power generation. The following sections consider whether the level of activity of project development, and the actions being taken by governments and industry players, in both the public and private sectors, appear to be consistent with renewable gas production being able to achieve a similar trajectory of scale-up.

Figure 4: Per cent per annum average annual scale up by scenario

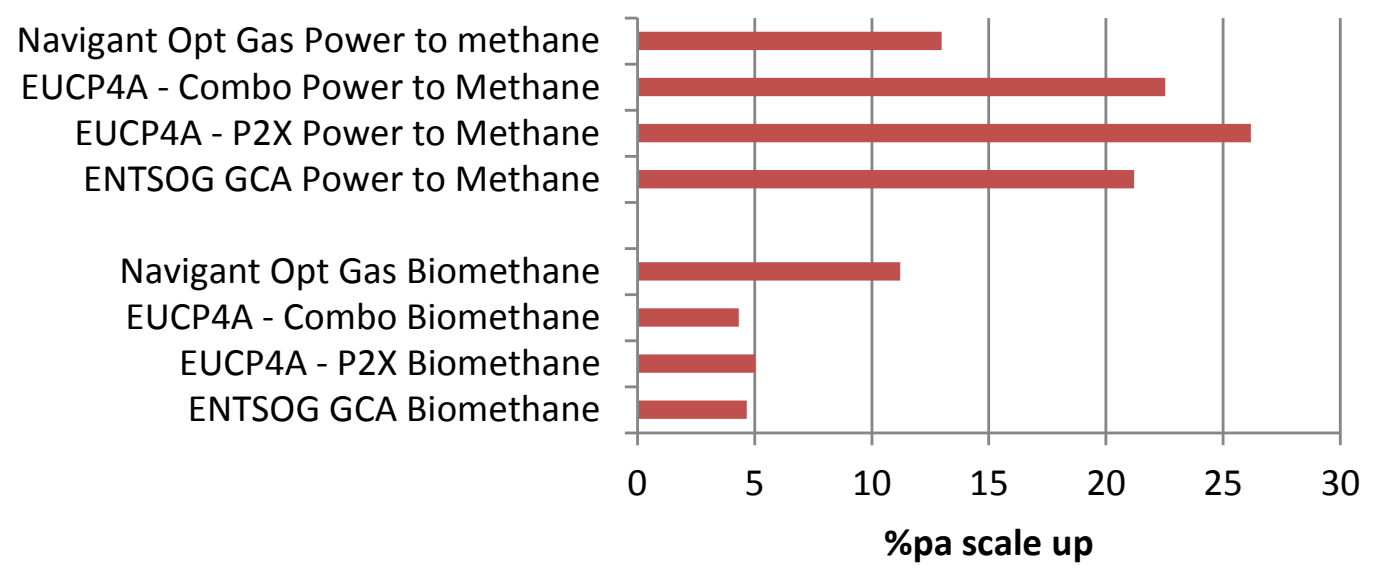

Source: Authors' analysis of stated sources

\footnotetext{
${ }^{17}$ Data taken from BP Statistical Review of World Energy 2018 (June 2018).
} 

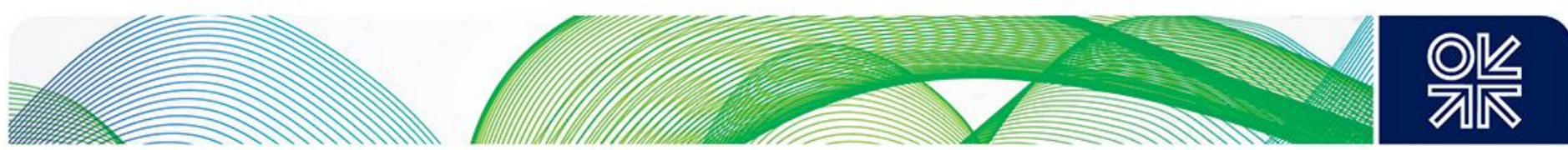

\section{Renewable gas (biomethane, renewable methane and hydrogen) database}

With input from a range of sources, OIES and SGI has built a database of over 550 actual European projects for biomethane, hydrogen and renewable methane injection into the gas grid. The database includes projects which are operational, under construction and at various phases of development. The review was performed based on several references. 18,19,20,21,22,23,24. The Appendix gives the list of names and locations of projects in the current database. Our intention is to update the database as more information becomes available.

\subsection{Biomethane}

The split of biomethane for grid injection projects by country in the EU is shown in Figure 5. Overall the database contains 497 operational biomethane projects (Figure 6b). Most of the projects are located in Germany (46 per cent), 20 per cent in the UK and 7 per cent in France and Switzerland. The total feed-in capacity of biomethane from these plants is approximately $240,400 \mathrm{~m}^{3} / \mathrm{h}$ (Figure 6a) - by comparison, $236,000 \mathrm{~m}^{3} / \mathrm{h}$ is reported in literature. ${ }^{25}$ The biogas plant availability (in terms of operational hours per year ( $\mathrm{h} / \mathrm{yr}$ ) is a key parameter in calculating the annual production potential. It has been proven that upgrading plants achieve technical availability up to the 96 per cent ${ }^{26}$ equivalent to $8,410 \mathrm{~h} / \mathrm{yr}$. The resulting annual nominal potential for biomethane can be estimated as 2.02 billion $\mathrm{m}^{3} / \mathrm{yr}(\mathrm{Bcm})$, equivalent to $21 \mathrm{TWh}$ or 73.2 PJ (calculated based on higher heating value (HHV)). According to the European Biogas Association Statistical report 2018, ${ }^{27}$ total biomethane production in Europe grew from $0.08 \mathrm{Bcm}$ in 2011 to $0.93 \mathrm{Bcm}$ in 2013 and to $1.94 \mathrm{Bcm}$ in 2017. The $1.94 \mathrm{Bcm}$ $(20 \mathrm{TWh})$ is remarkably close to the $2.02 \mathrm{Bcm}(21 \mathrm{TWh})$ calculated above, indicating that biomethane plants are operating at high capacity factors in excess of 90 per cent.

Between 2013 and 2017 biomethane production grew at an average annual rate of 20 per cent, so if growth were to continue at this rate the scenarios considered in Section 2 could be achieved. However, as shown in Figure 6(a), the increase in capacity was on a downward trend in 2016 and 2017 on account of changes in regulatory incentives. We await with interest the growth rates for 2018 and 2019 when these become available.

\footnotetext{
${ }^{18}$ European Power to Gas Platform, Online. Available at 〈http://europeanpowertogas.com

${ }^{19}$ HyDeploy at Keele University Online, available at https://hydeploy.co.uk/>

${ }^{20}$ Engie, Website: The GRHYD demonstration project - ENGIE, Online, available at https://www.engie.com/en/innovationenergy-transition/digital-control-energy-efficiency/power-to-gas/the-grhyd-demonstration-project/

${ }^{21}$ Quarton, C. and Samsatli, S. (2018). Power-to-gas for injection into the gas grid: What can we learn from real-life projects, economic assessments and systems modelling? Science Direct, Renewable and Sustainable Energy Reviews, 98, 302-316. 22 Sadler, D., Cargill, A., Crowther, M., Rennie, A., Watt, J., Burton, S. and Haines, M. H21 Leeds City Gate. (2016). URL: http://www.northerngasnetworks. co.uk/document/h21-leedscity-gate/

${ }^{23}$ International Energy Agency (IEA), Hydrogen Production \& Distribution. (2007). IEA.

${ }^{24}$ H21 NOE (2018): H21 North of England, November 2018. https://www.northerngasnetworks.co.uk/event/h21-launchesnational/

${ }^{25}$ Prussi, M., Padella, M., Conton, M., Postma, E. and Lonza, L. (2019). Review of technologies for biomethane production and assessment of EU transport share in 2030. ScienceDirect, Journal of Cleaner Production, 222, 565-572.

${ }^{26}$ Bauer F., Hulteberg C., Persson T., Tamm D. (2013). Biogas Upgrading-Review of Commercial Technologies. SGC Rapport 270. Svenskt Gastekniskt Center AB

${ }^{27}$ http://european-biogas.eu/wp-content/uploads/2019/05/EBA report2018 abriged A4 vers12 220519 RZweb.pdf
} 

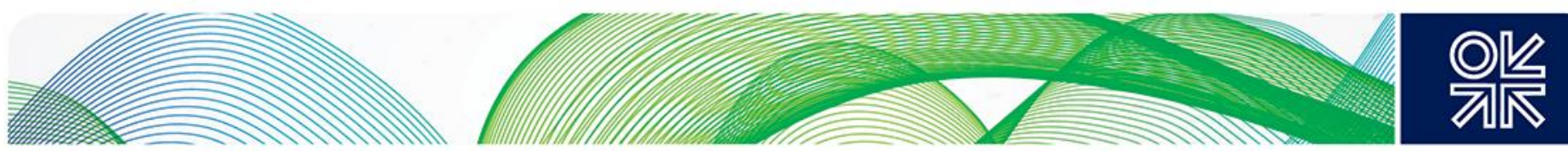

Figure 5: Biomethane for grid injection projects in Europe

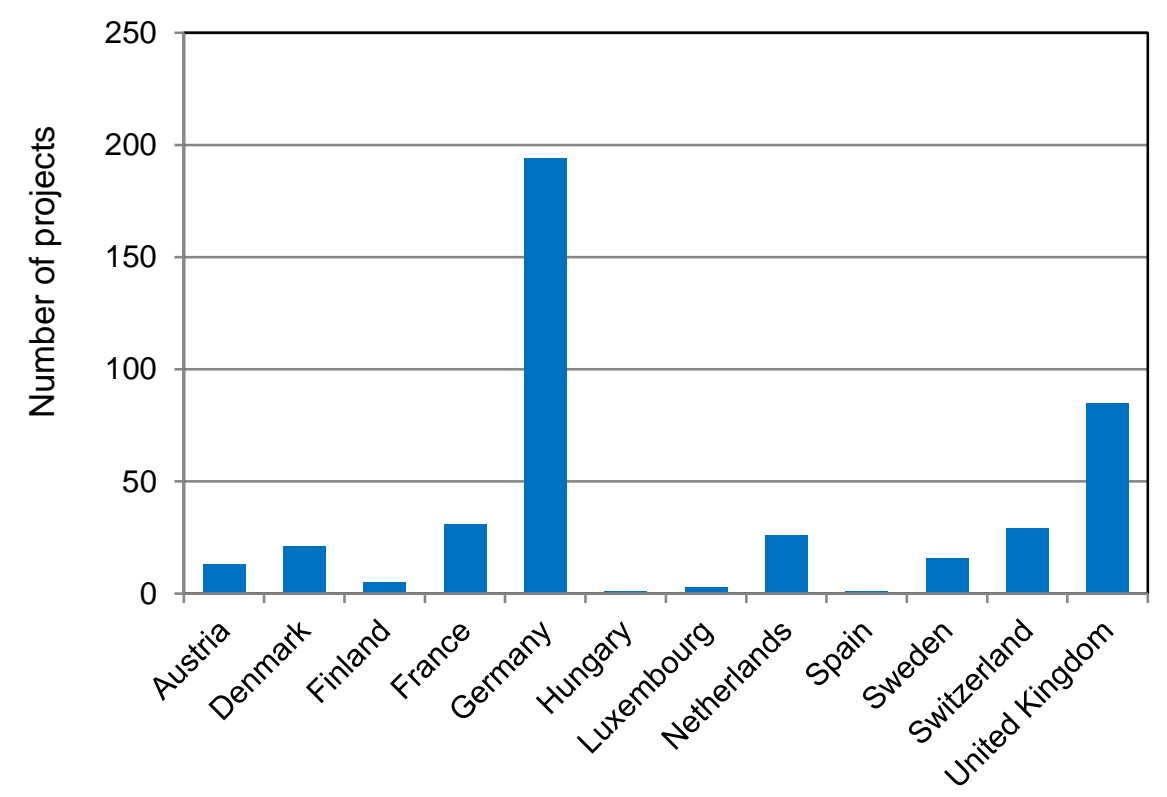

Source: Authors' analysis

Figure 6: (a) Biomethane feed in capacity

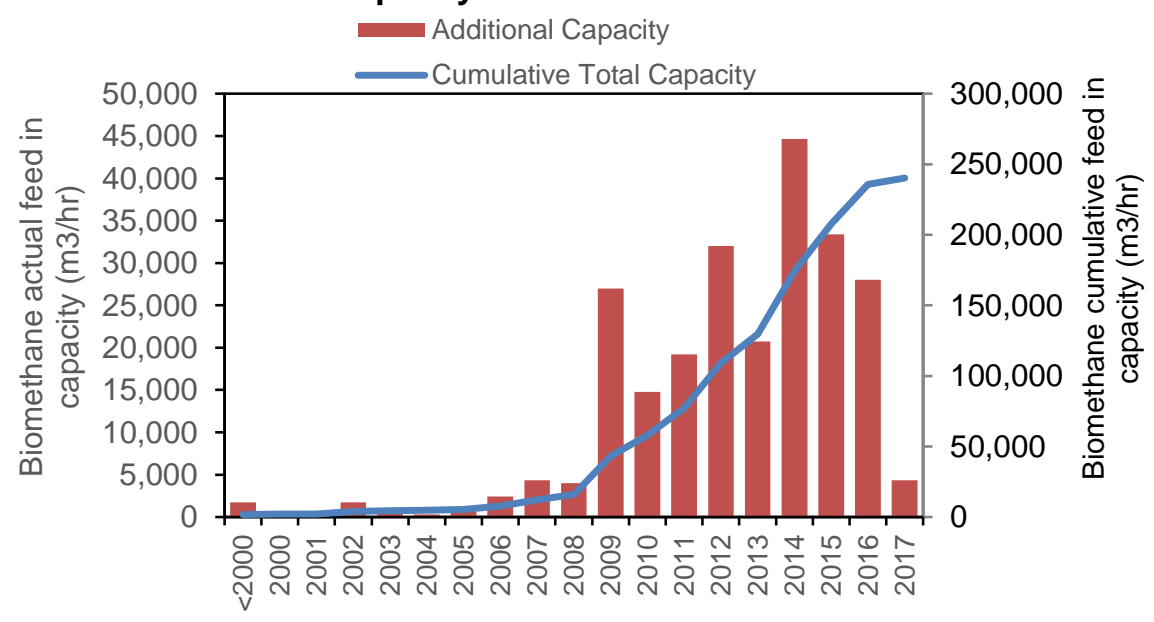

Source: Authors' analysis 

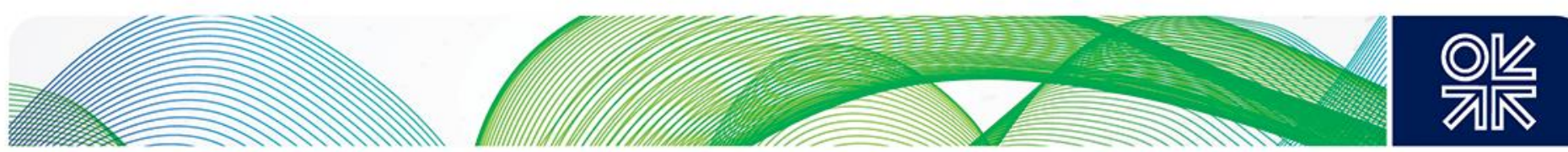

Figure 6: (b) Associated number of plants (the average capacity growth is $6.88 \%$, the max is $21 \%$ and minimum $1.2 \%$ )

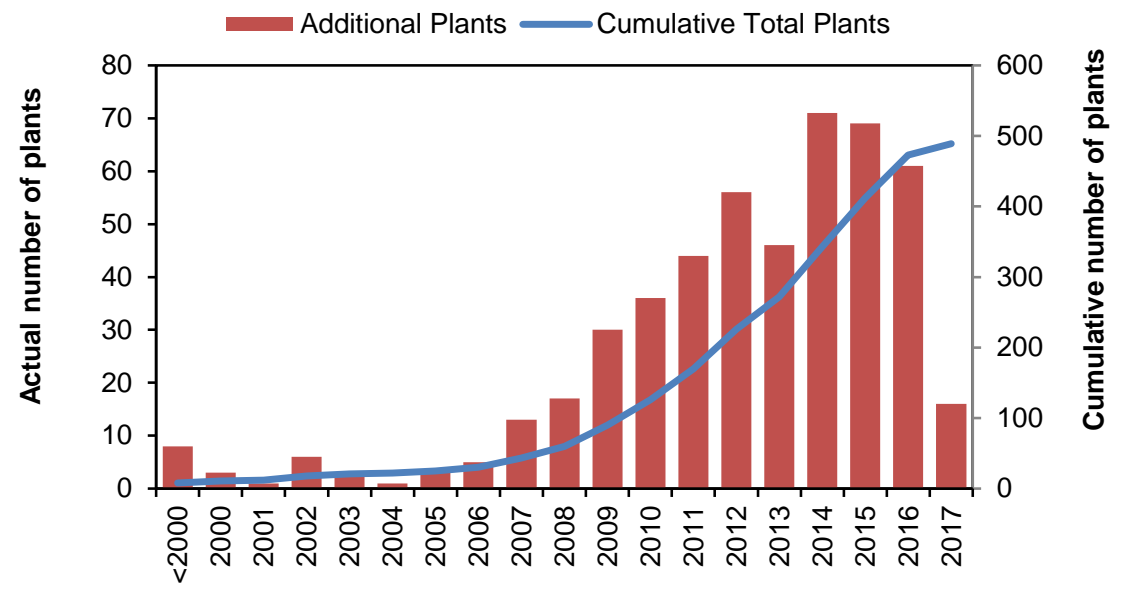

Source: Authors' analysis

Various techniques are available to upgrade biogas to biomethane. These techniques include physical and chemical absorption, adsorption, membrane and cryogenic separation. ${ }^{28}$ The most common technology applied in the EU in terms of number of plants is chemical scrubbing (Table 4); however, 22 per cent of biogas produced is from water scrubbing (Figure 7). Cryogenic separation only occurs in one plant located in the Netherlands (Table 4).

Biomass gasification is another technology for efficient utilization of biomass. Compared to anaerobic digestion, the claimed advantage of biomass gasification is its ability to produce biomethane on a large scale. ${ }^{27}$ However, as shown in Table 4, very few plants have successfully demonstrated biomethane production via gasification. 

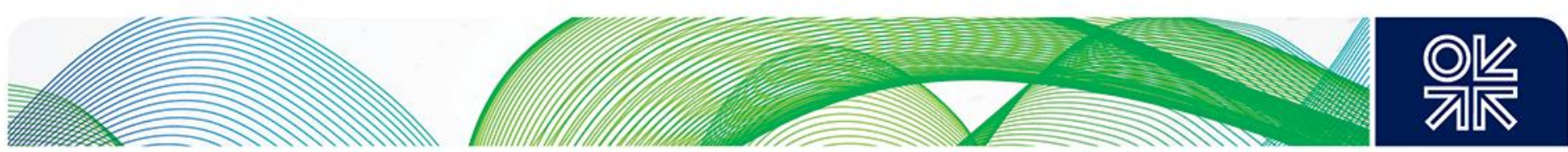

Table 4: Breakdown of biomethane production routes (2017)

\begin{tabular}{|c|c|c|}
\hline Technology type & Number of Plants & Location \\
\hline Cryogenic separation & 1 & Netherlands \\
\hline Water scrubbing & 124 & $\begin{array}{l}\text { Germany, Denmark, Finland, France, } \\
\text { Sweden, UK }\end{array}$ \\
\hline Chemical Scrubbing & 102 & $\begin{array}{l}\text { Austria, Denmark, Germany, Luxembourg, } \\
\text { Netherlands, } \\
\text { Switzerland, UK }\end{array}$ \\
\hline $\begin{array}{l}\text { Pressure } \quad \text { Swing } \\
\text { Adsorption }\end{array}$ & 68 & $\begin{array}{l}\text { Germany, Netherlands, Spain, Sweden, } \\
\text { Switzerland, France, Finland and Austria }\end{array}$ \\
\hline Membrane separation & 82 & Switzerland, United Kingdom \\
\hline Membrane/cryogenic & 7 & UK \\
\hline Physical scrubbing & 37 & $\begin{array}{l}\text { Austria, Denmark, Germany, Luxembourg, } \\
\text { Netherlands, Norway and Sweden }\end{array}$ \\
\hline Biomass gasification & 3 & France, Sweden and Netherlands \\
\hline
\end{tabular}

Source: Authors' analysis

Figure 7: Contribution from each upgrading technology, and relative share of the total current EU feed in capacity (2017)

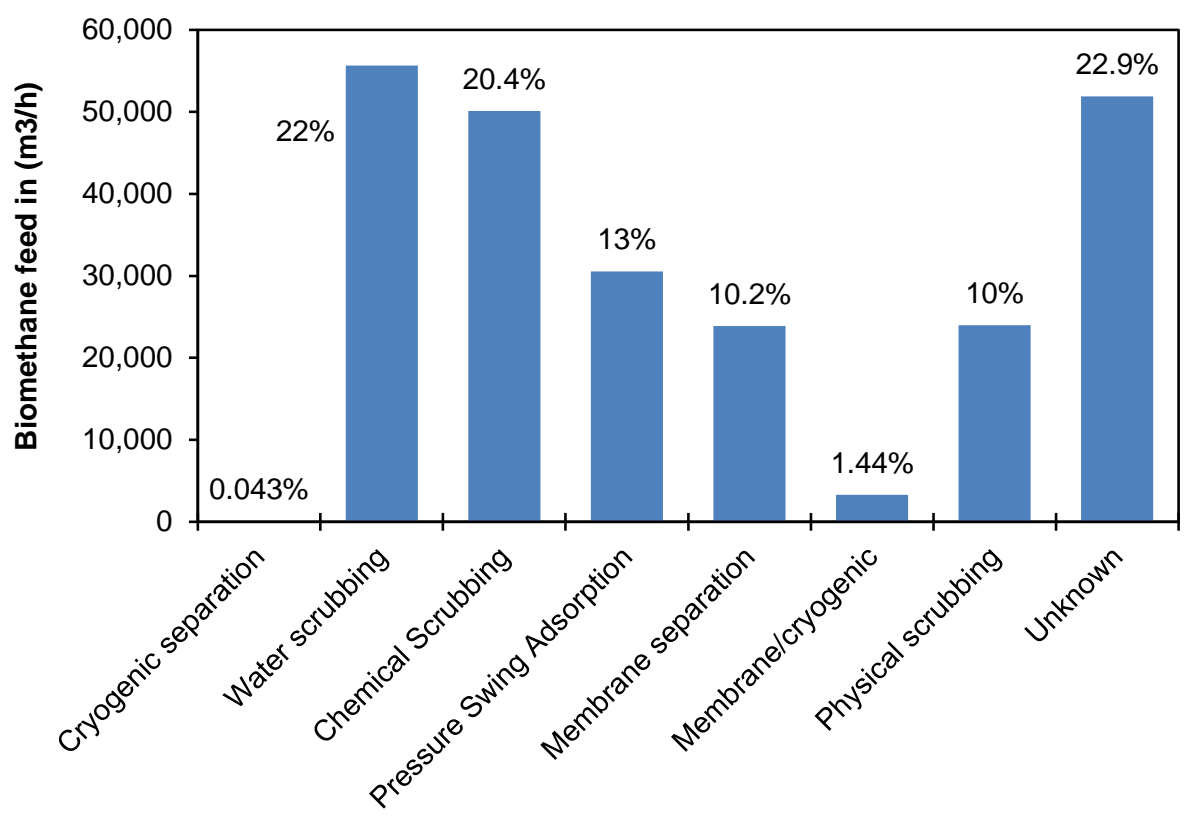

Source: Authors' analysis

Biomethane can be produced from various substrates (ie. feedstocks):

- $7 \mathrm{PJ}(1.9 \mathrm{TWh})$ is from 56 plants using agricultural residues, manure and plant residues;

- $\quad 28.1 \mathrm{PJ}$ (7.8 TWh) is from 168 plants using energy crops;

- 4 PJ (1.1 TWh) is from 14 plants using industrial organic waste from food and beverage industries;

- $\quad 0.5 \mathrm{PJ}(0.1 \mathrm{TWh})$ is from 4 plants using biogas from landfill; 

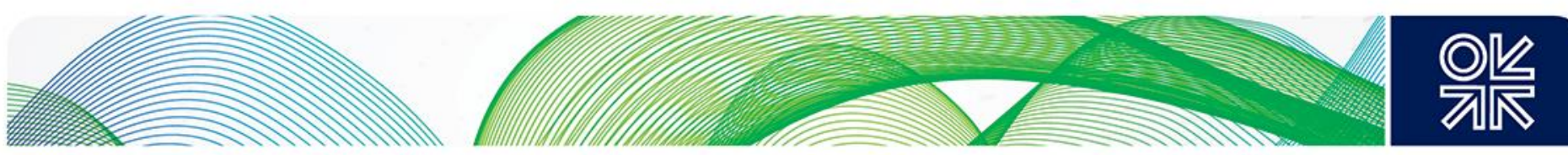

- $\quad 5.5$ PJ (1.5 TWh) is from 38 plants using Municipal Solid Waste (both bio and municipal waste);

- $2 \mathrm{PJ}$ (0.6 TWh) is from 31 plants using sewage sludge.

The large number of production facilities using energy crops is largely as a result of government policy support in Germany. This policy was changed in 2014 after the adverse effects of large scale production of energy crops had been realised. ${ }^{29}$ For future growth in biomethane to be sustainable, it will need to be predominantly using waste feedstocks.

\subsection{Renewable hydrogen and renewable methane (other than biomethane)}

The database also contains 43 renewable hydrogen projects: 34 per cent are located in Germany, 18 per cent in the UK, 11 per cent in France and Netherlands, and 8 per cent in Austria (Figure 8). Also, 15 power to methane projects were identified in the EU - 31 per cent in Germany, and 13 per cent in both Norway and Netherlands (Figure 9).

Figure 8: Hydrogen for grid injection projects in Europe

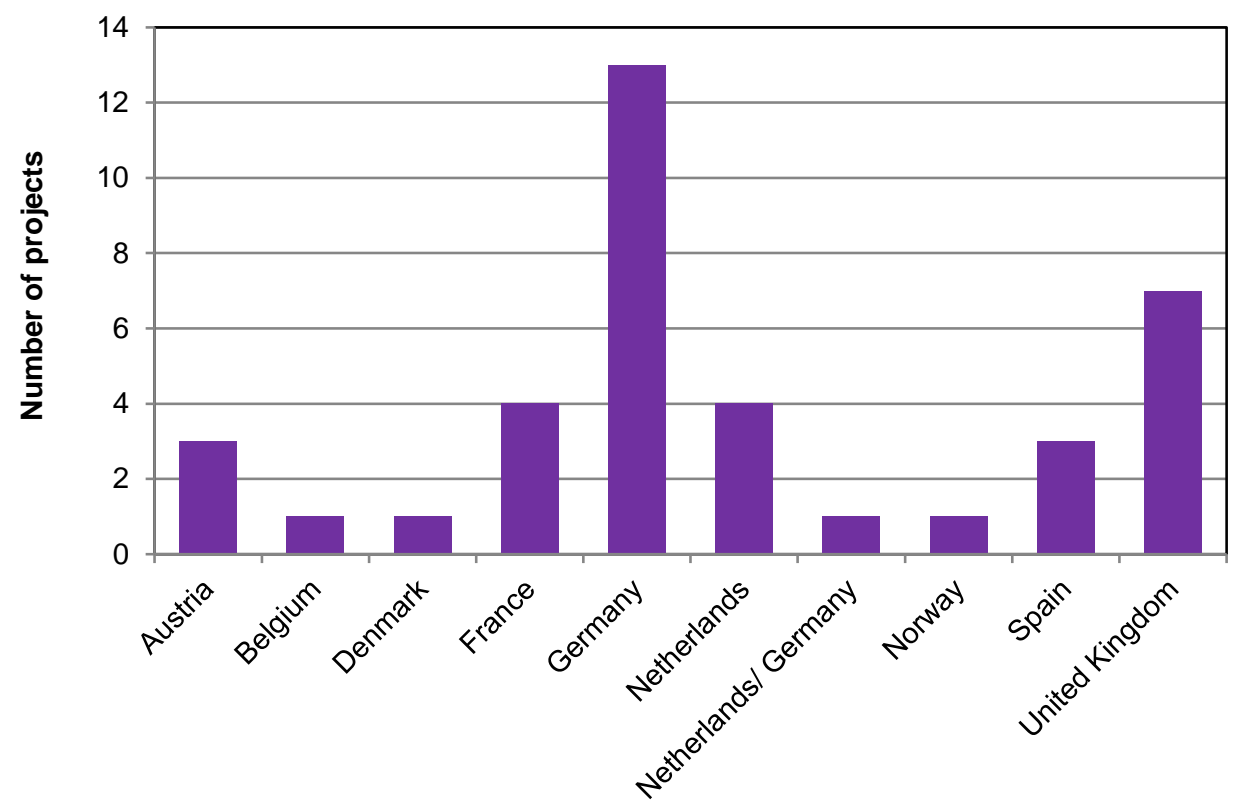

Source: Authors' analysis

\footnotetext{
${ }^{29}$ e.g. growth of energy crops tends to increase pressure on food production: see Appel, F. et al. (2016). 'Effects of the German Renewable Energy Act on structural change in agriculture - The case of biogas'. ScienceDirect, Utilities Policy, 41, 172-182. https://doi.org/10.1016/j.jup.2016.02.013
} 

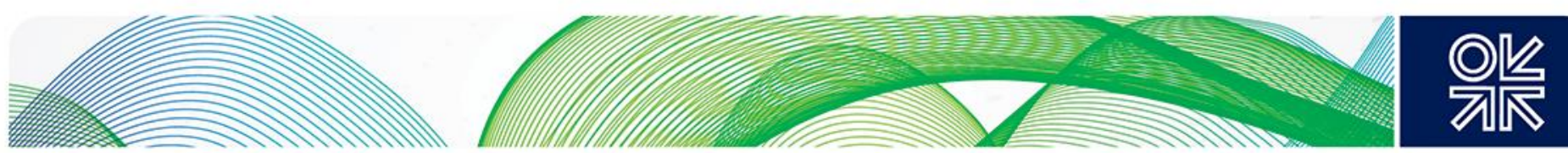

Figure 9: Renewable methane for grid injection projects in Europe

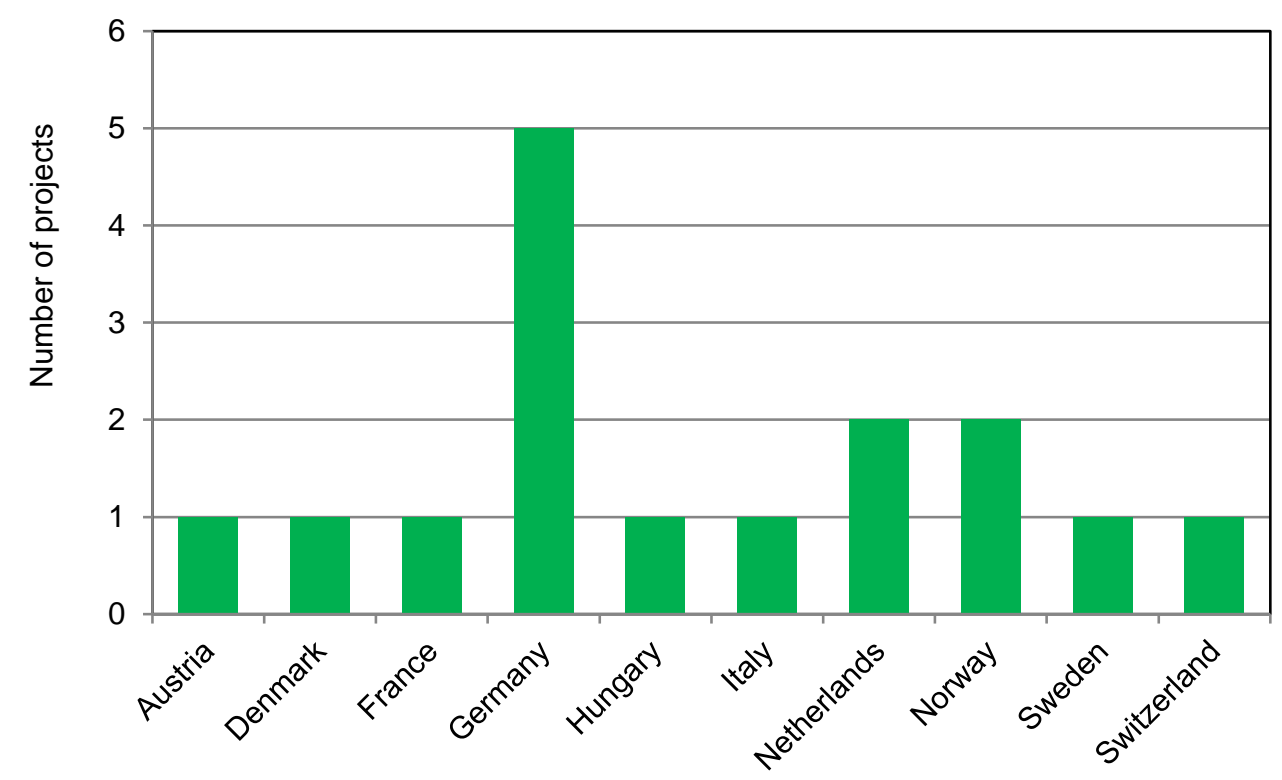

Source: Authors' analysis

Hydrogen and renewable methane (other than biomethane) can be produced using various technologies. Projects in Europe are largely dominated by power to hydrogen and power to methane (Table 4). Other hydrogen production technologies include Steam Methane Reforming (SMR) with Carbon Capture and Storage (CCS), Autothermal Reforming (ATR) with CCS, and thermal solar hydrogen plant, but there are very few projects planning to use these technologies. Note that in most cases where these projects do not use 100 per cent renewable power or they do not capture and store 100 per cent of carbon produced they are not strictly 'renewable'. However, they are relevant as demonstrations of technologies which could, in future, produce low-carbon or renewable carbon gaseous fuels.

Table 5: Hydrogen and renewable methane production pathways

\begin{tabular}{|l|c|l|}
\hline Technology type & Number of Projects & Location \\
\hline SMR with CCS & 4 & UK, France and Netherlands \\
\hline ATR with CCS Solar & 1 & UK \\
\hline $\begin{array}{l}\text { Thermal } \\
\text { Hydrogen }\end{array}$ & 1 & Spain \\
\hline Power to hydrogen & 29 & $\begin{array}{l}\text { Germany, UK, France, Spain, } \\
\text { Netherlands, Austria, Norway }\end{array}$ \\
\hline Power to methane & 11 & $\begin{array}{l}\text { Germany, Switzerland, Italy, Denmark, } \\
\text { Netherlands, Austria, Hungary }\end{array}$ \\
\hline
\end{tabular}

Source: Authors' analysis

Figure 10 shows the status of hydrogen and renewable methane projects at all stages of development. To explain the category descriptions used, some examples are given below: 

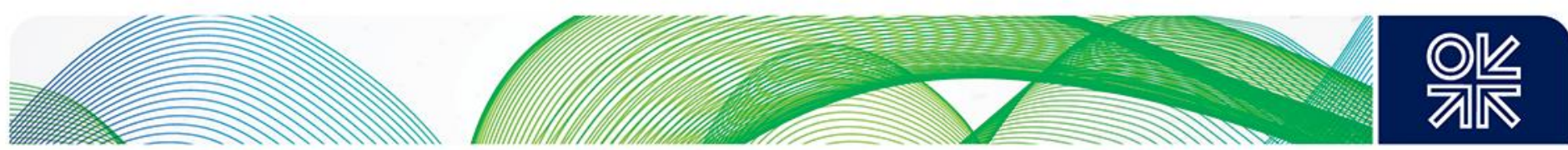

- Completed (once operational, but now shut down or dismantled) projects: e.g. a small 7 GWh/year power to hydrogen in Germany which stopped operation in January 2013;

- Development (before final investment decision and generally more advanced than 'feasibility'): Some projects in this category include the 'Element One' $0.5 \mathrm{TWh} / \mathrm{year}$ power to hydrogen (100MW electrolyser) project in Germany, and the 'Hynet' seven TWh/year ATR with CCS project in the UK;

- Feasibility: (at an early stage of consideration, requiring considerably more work before approaching final investment decision). For example, the 'H21' approximately $100 \mathrm{TWh} /$ year SMR with CCS project in the UK, and another $0.5 \mathrm{TWh} /$ year power to hydrogen project in Germany.

- Operational: The database contains four operational power to methane plants, and seven operational power to hydrogen plants. (We have not included some very small power to gas plants - that is, less than one megawatt (MW) electrolyser capacity - as they are not relevant to our interest in scaling up the technology). Two of the power to methane plants are located Germany (started in 2013 and 2018 respectively). Five of the power to hydrogen plants are also located in Germany.

- Under construction: Nine plants are under construction, five of these are power to methane plants.

As discussed further below, the relatively small number of projects in the feasibility and development phase does not provide confidence that the industry is on track to meet the large scale up ambitions of the reports in Section 2.

\section{Figure 10: Status of Hydrogen and renewable methane for grid injection projects in Europe} (2019)

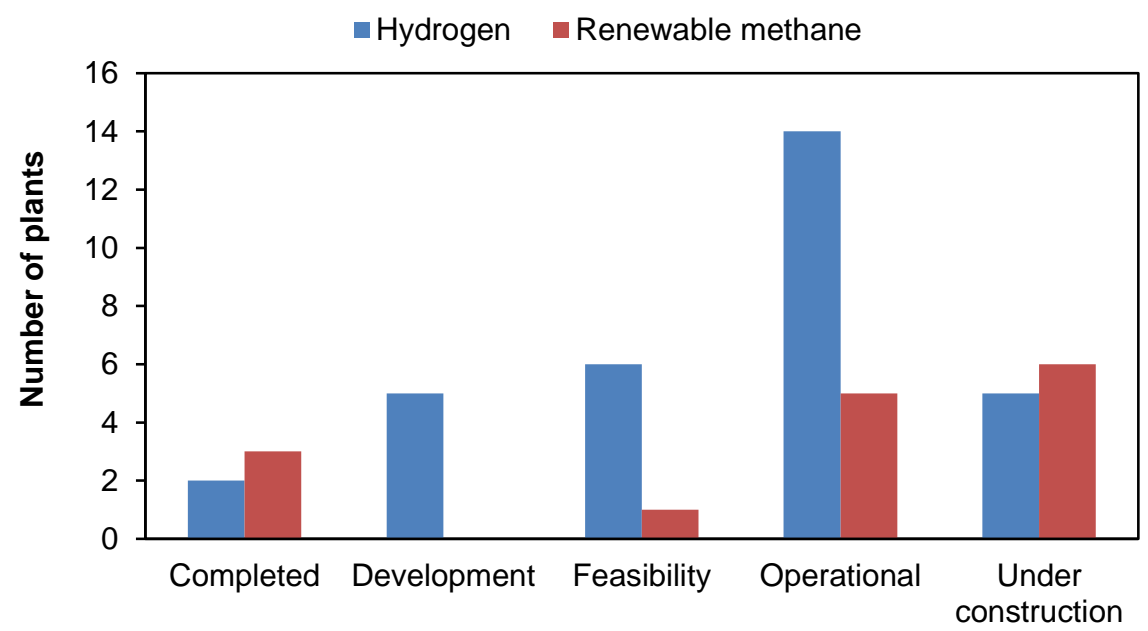

Source: Authors' analysis 

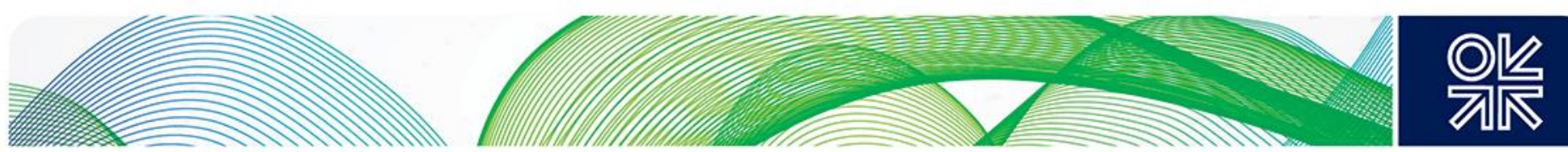

Table 6: Associated hydrogen output capacity for projects (status in 2019)

\begin{tabular}{|c|c|c|}
\hline Project Status & $\begin{array}{l}\text { P2G Hydrogen output } \\
\text { capacity (GWh/year) }\end{array}$ & $\begin{array}{l}\text { SMR/ATR with CCS } \\
\text { hydrogen } \\
\begin{array}{l}\text { output } \\
\text { capacity (GWh/year) }\end{array}\end{array}$ \\
\hline Completed & 8 & \\
\hline Development & 985 & \\
\hline Feasibility & 2,000 & 130,000 \\
\hline Operational & 36 & 590 \\
\hline Under construction & 28 & 0 \\
\hline Unknown & 4,205 & \\
\hline
\end{tabular}

Source: Authors' analysis

Table 5 shows the intended hydrogen output quantity from the projects in the database. It can be seen that the scale of production from projects using SMR/ATR with CCS technology ('blue hydrogen') is an order of magnitude larger than P2G projects. Thus, the scale up challenge for methane reforming with CCS is less than for P2G, but it is also notable that there is only one such operational project in Europe, at Port Jerome in France (with carbon capture but not storage), supplying hydrogen to ExxonMobil's adjacent refinery, and using the captured $\mathrm{CO} 2$ in various food industry and industrial applications. CCS remains very controversial technology in many European countries (notably Germany, Austria and Italy).

Where available, data on total project budget was also collected. The total budget per unit of electrolyser capacity is shown in Figure 11 for power to hydrogen. Figure 11 is based on the following limited number of projects for which data is available:

- $0.5 \mathrm{MW}$ electrolyser in the UK

- $\quad 1.2$ MW Polymer Electrolyte Membrane (PEM) electrolyser in Denmark

- $6 \mathrm{MW}$ PEM electrolyser in Austria

- $10 \mathrm{MW}$ electrolyser in Germany

- $100 \mathrm{MW}$ electrolyser in Germany

Figure 11: Unit project cost. The unit project cost is the ratio of the total project budget and the electrolyser capacity

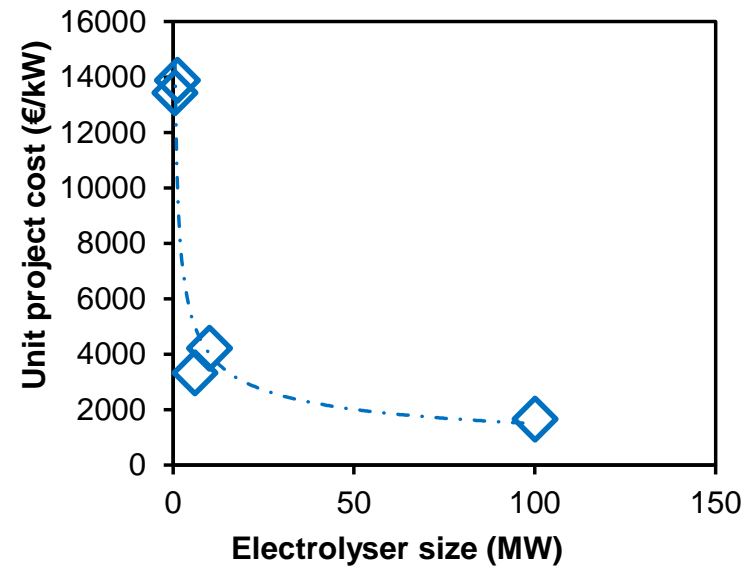

Source: Authors' analysis 

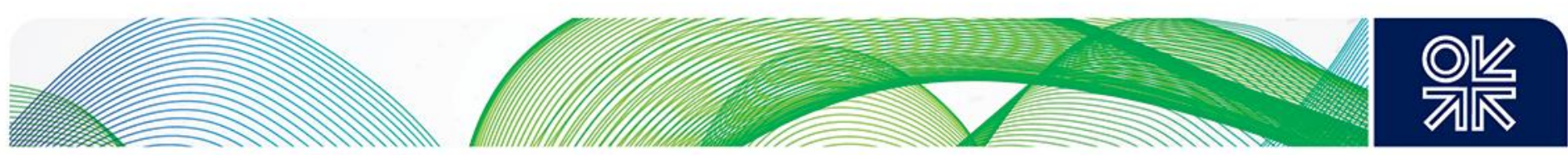

Figure 11 shows that cost advantages are already obtainable from increased scale. For example, the budgeted project cost associated with a $1.2 \mathrm{MW}$ electrolyser is $€ 16.6$ million, $10 \mathrm{MW}$ electrolyser is $€ 42.1$ million and $100 \mathrm{MW}$ is $€ 66.5$ million. More details on comparative costs are given in the next section.

\section{Current costs and potential cost-reduction pathway if scale up progresses in line with target scenarios}

A systematic review of literature considered a number of cost estimates across a range of EU countries, years and plant scales. ${ }^{22,30,31,32,33}$ Figure 12 shows the unit cost estimates (in €/MWh) ${ }^{34}$ for 2018 and projections for 2030 and 2050. As can be seen, the cost estimates for different techniques producing hydrogen, biomethane and renewable methane vary significantly. The unit production cost is made up of annualized investment costs, annual operation and maintenance costs (including feedstock costs) but excludes profit margin. The significant range of cost estimates is driven by the different processes and technologies used to generate these gases.

The production cost for green hydrogen depends on CAPEX for electrolyser and balance of plant, feedstock electricity costs, capacity factor expressed in full-load hours (FLH) and electrolyser system energy efficiency. Feedstock electricity costs and capacity factor are driven by the production route for electricity. For blue hydrogen, the CAPEX of both production processes consists of the $\mathrm{H} 2$ production plant (reactor), carbon capture installation, carbon transport infrastructure, and $\mathrm{CO}_{2}$ storage facilities. ${ }^{33,34}$

Biomethane costs depends heavily on feedstocks, the lower end is when manure and agricultural residues are used and the higher end is associated with energy crops. Overall unit biomethane costs are currently estimated in the range $€ 60-80 / \mathrm{MWh}$ and little further unit cost reduction is assumed, with unit costs around €50/MWh in 2050.

The average capital costs associated with hydrogen production technologies range from around $€ 300$ per kW using SMR to over $€ 2,000$ per kW using small scale electrolysis. SMR is one of the cheapest production technologies in capital cost terms, with the additional cost of CCS adding less than $€ 100$ per kW ( 30 per cent) to the average capital cost. Unit costs of SMR with CCS are expected to be in the range $€ 40-60 / M W h$ by 2050.

\footnotetext{
${ }^{30}$ IEA Greenhouse gas R\&D Programme Technical report. (2017). Techno-Economic Evaluation of SMR Based Standalone (Merchant) Hydrogen Plant with CCS. https://ieaghg.org/exco_docs/2017-02.pdf

${ }^{31}$ Speirs, J., Balcombe, P., Johnson, E., Martin, J., Brandon, N. and Hawkes, A. (2018). 'A greener gas grid: What are the options'. SGI, Energy Policy, 118, 291-297.

${ }^{32}$ NREL. (2009)., 'Current (2009) State-of-the-Art Hydrogen Production Cost Estimate Using Water Electrolysis'.

${ }^{33}$ Navigant report. (2019). 'Gas for Climate. The optimal role for gas in a net-zero emissions energy system'. https://www.gasforclimate2050.eu/files/files/Navigant Gas for Climate The optimal role for gas in a net zero emissions energy system March 2019.pdf

${ }^{34}$ All costs in this paper are on the basis of $€ / 2018$
} 


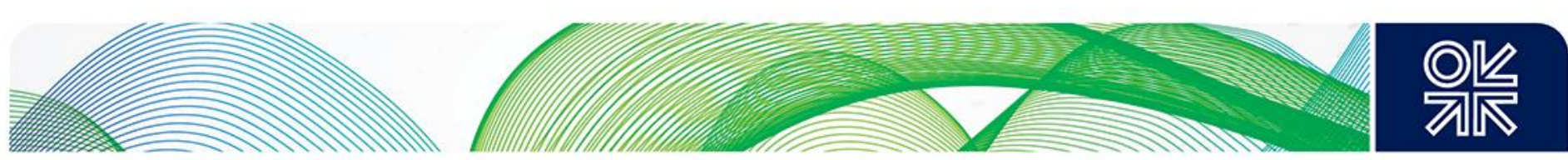

Figure 12: Renewable gas production costs in 2018, and projections for 2030 and 2050
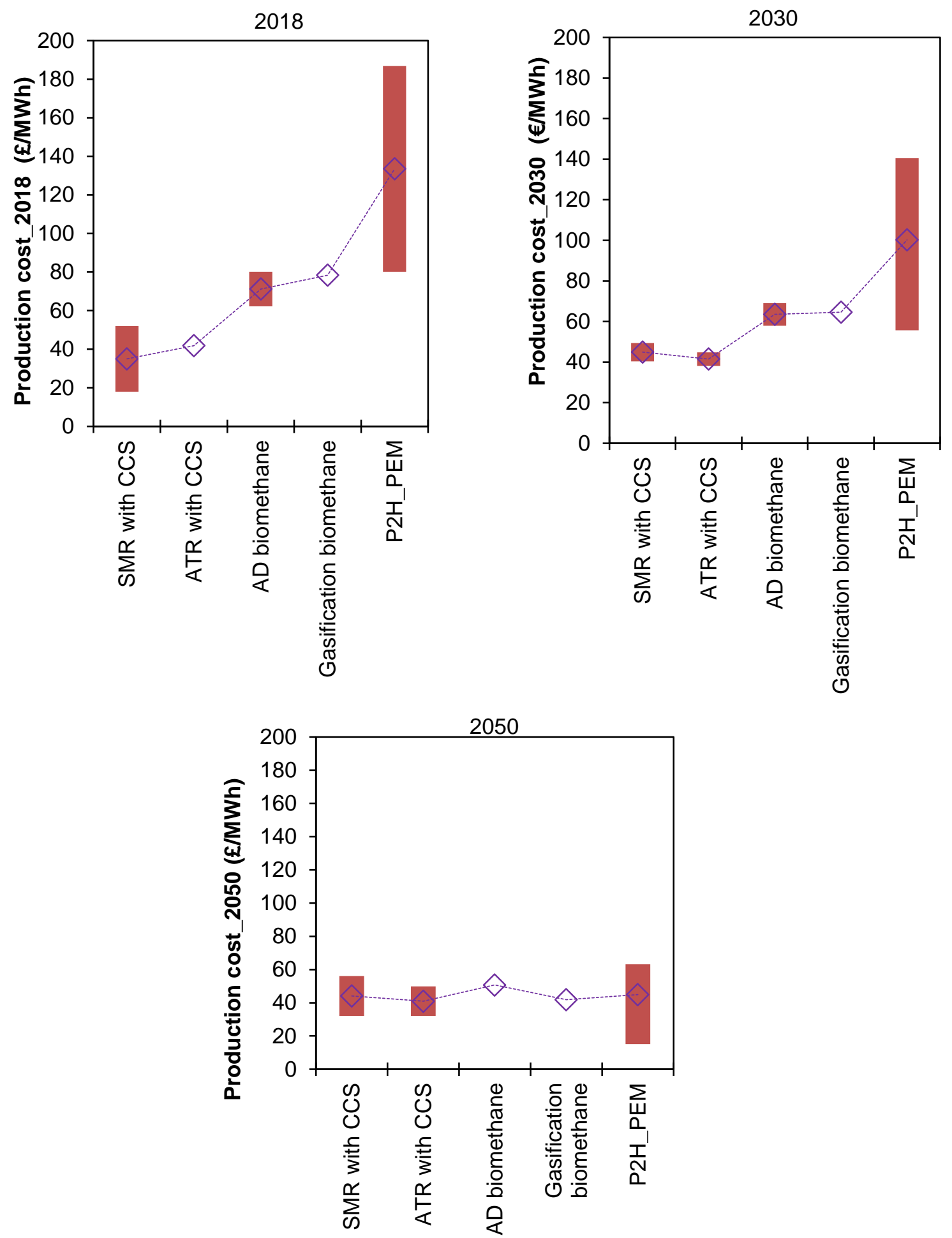

Source: Authors' analysis 

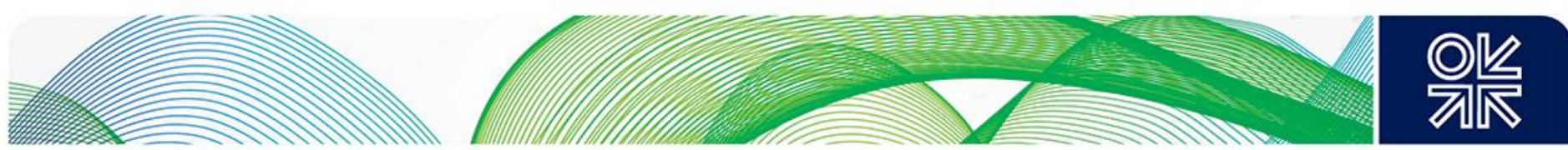

According to the Navigant report, continuous deployment and technology scale up are the key factors contributing to the projected 2050 cost reduction of new technologies. ${ }^{34}$

- For biomethane production via gasification, plants are expected to scale up from around 3MW capacity today to around 200MW capacity (each producing $240 \mathrm{TWh}$ of biomethane annually) by 2050 . This scale up is predicted to reduce CAPEX by around 50 per cent and OPEX by around 40 per cent. ${ }^{32}$ This, combined with increasing efficiency (from $65-75$ per cent), is predicted to reduce unit costs from around $€ 88 / \mathrm{MWh}$ today to around $€ 47 / \mathrm{MWh}$ by 2050 . The costs for 2018 are from the Gothenburg Biomass Gasification project. ${ }^{35}$ The cost breakdown for biomethane from anaerobic digestion is provided in Figure 13.

- Cost reduction for green hydrogen is from expected technology maturity leading to reduced electrolyser system costs mainly from economies of scale, cheaper electricity, and improvements in system energy efficiency. ${ }^{31-34}$ The Navigant report focuses on PEM electrolyser technology and assumes that system costs will reduce from $€ 800-1000 / \mathrm{kW}$ today to $€ 420 / \mathrm{kW}$ by 2050 . Depending on the cost of electricity, this is predicted to lead to unit hydrogen production costs in the range $€ 44-61 / \mathrm{MWh}$. The cost of electricity depends on the source. The Navigant report considers four sources: curtailed electricity, dedicated production from North Sea offshore wind power, dedicated production from Southern European photovoltaic (PV) and dedicated production from Southern European hybrid sources (PV plus onshore wind power). The different sources demonstrate the impact of different capacity factors and electricity feedstock costs.

- For power-to-methane, currently investment costs for the methanation reactor are very high and there is a large uncertainty on the investment cost, mainly due to the lack of commercially deployed units. The Navigant report predicts an incremental cost of €20/MWh for conversion of green hydrogen to methane, resulting in a methane cost in the range €65-80/MWh in 2050. The Navigant report assumes 147 TWh of renewable methane produced in 2050 with 80 per cent methanation reaction efficiency. The report also assumes a specific methanation reactor CAPEX of $€ 400 / \mathrm{kW}$ with a lifetime of 20 years.

Figure 13: Production costs for biomethane based on anaerobic digestion

- Capital costs $\approx \mathrm{O} \& \mathrm{M}$ costs $\approx$ Feedstock costs

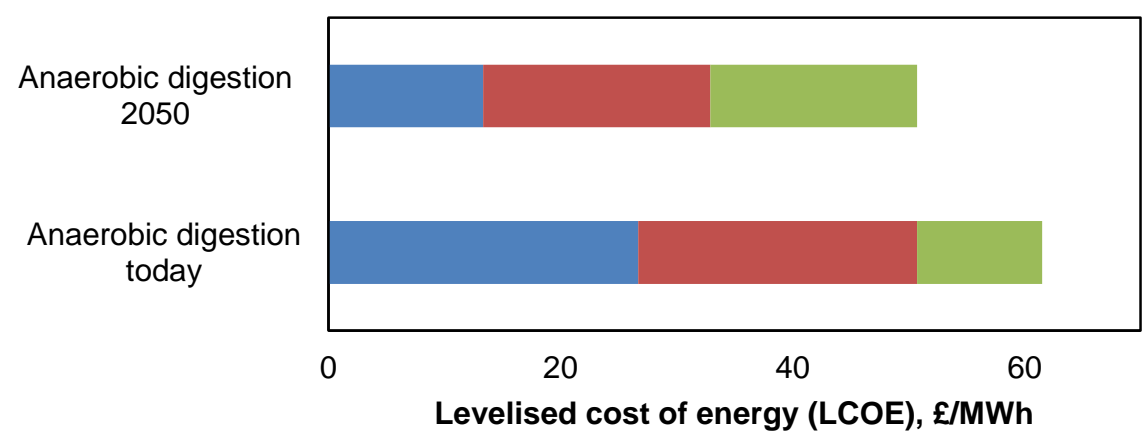

Source: Navigant, Gas for Climate March 2019

These numbers demonstrate that there are very significant aspirations for achievable cost reductions as a result of production scale up. In reality, it is clearly very difficult to make accurate predictions of what can be achieved, underlining the importance of making significant progress on building larger capacity facilities as soon as possible. Only such real world experience can give confidence regarding achievable cost reductions.

\footnotetext{
${ }^{35} \mathrm{GoBiGas}$ 2018. Demonstration of the Production of Biomethane from Biomass via Gasification. https://www.chalmers.se/SiteCollectionDocuments/SEE/News/Popularreport GoBiGas results highres.pdf
} 

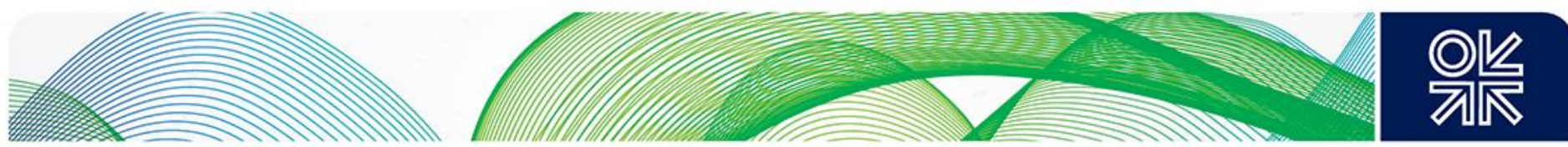

\section{Benchmarking cost reduction estimates for intended development pathways}

In general, increase in experience gained from manufacture and use of a technology causes specific costs to fall. It is interesting to compare the projected fall in costs for the various renewable gas technologies with the actual fall in costs for renewable power generation in recent years, as a benchmark for what might be achievable. It should, however, be recognised that the rate of decrease in renewable power generation costs (particularly solar PV) has been very rapid and faster than many had predicted. ${ }^{36}$ There is no guarantee that renewable gas technology will be able to replicate this reduction in costs.

The fall in costs has been studied for the Solar PV module as shown in Figure 14.37 The Learning Curve (LC) of the module was determined by the evolution of spot prices (average selling price). The LC predicts how the costs of a technology evolves based on historical trends. The LC is also referred to as the learning rate. Most of the LC from literature is close to 80 per cent, or a 20 per cent progress ratio $(P R=1-L C) .{ }^{35,38}$ A Learning Curve of 80 per cent means the new cost of production is 80 per cent of the previous level each time the cumulative manufactured quantity doubles. Figure 14 shows learning occurs at a faster rate during the early years of deploying the module. A certain level of manufacturing maturity is reached after which doubling production quantity requires more time. Empirical evidence demonstrates that a strong correlation exists between experience and falling costs for various electricity generation technologies, with costs declining at a certain rate (called the learning rate) for each doubling of the technology's capacity. ${ }^{39,40}$ Assuming that the learning rates observed in the past will remain stable in the future, changes in the cost of electricity generation technologies can be anticipated.

\footnotetext{
36 https://cleantechnica.com/2018/02/11/solar-panel-prices-continue-falling-quicker-expected-cleantechnica-exclusive/

${ }^{37}$ Elshurafa, A., Albardi, S., Bigerna, S. and Bollino, C. (2018). 'Estimating the learning curve of solar PV balance-of-system for over 20 countries: Implications and policy recommendations'. ScienceDirect, Journal of Cleaner Production, 196, 122-134 ${ }^{38}$ Mauleón I. (2016). 'Photovoltaic learning rate estimation: issues and implications'. ScienceDirect, Renewable and Sustainable Energy Reviews, 65, 507-524.

${ }^{39}$ McDonald, A., Schrattenholzer L. (2001). 'Learning rates for energy technologies'. ScienceDirect, Energy Policy 29, 255-261. https://www.sciencedirect.com/science/article/pii/S0301421500001221

${ }^{40}$ Rubin, E.S., Azevedo, I.M.L., Jaramillo P., Yeh S. (2015). 'A review of learning rates for electricity supply technologies'. ScienceDirect, Energy Policy 86, 198-218.
} 

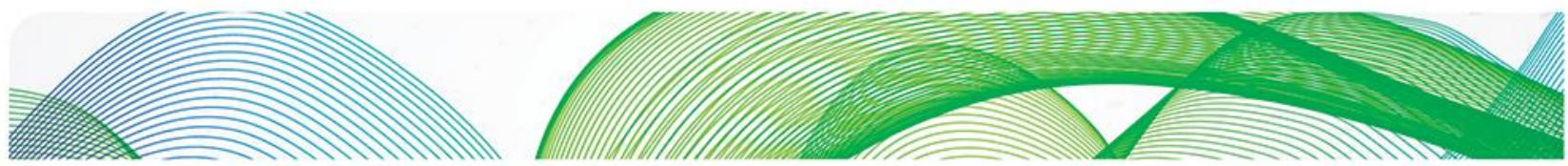

Figure 14: Learning curve of the solar PV module.

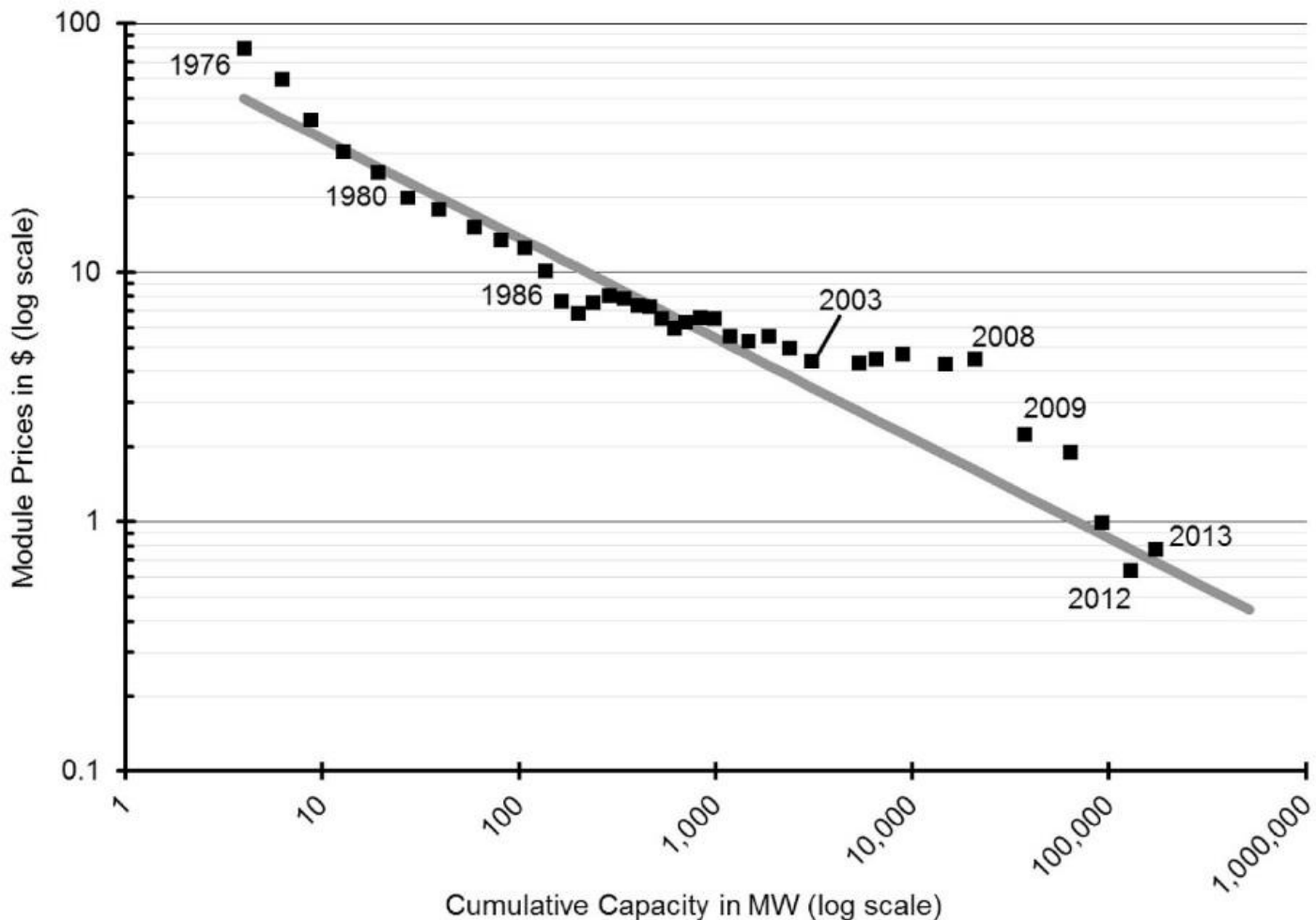

Source: Data from IRENA. Showing how the solar PV cost has evolved based on historical trends. Prices are plotted against global cumulative production. Since the axes are in log-scale, the exponential decay is transformed into a linear decrease. The years are included for completeness. 

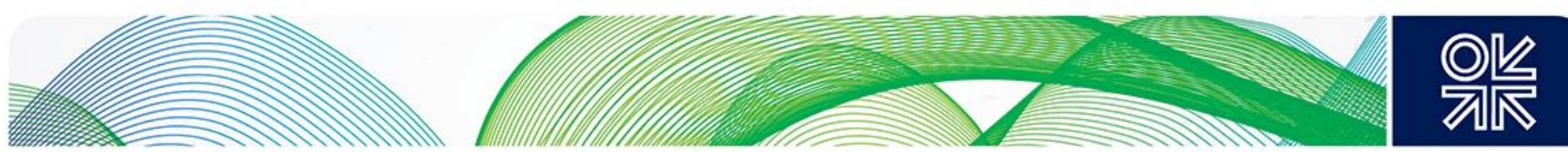

Figure 15: Estimates of plausible future learning rate ranges for several important electricity generation technologies ${ }^{41}$

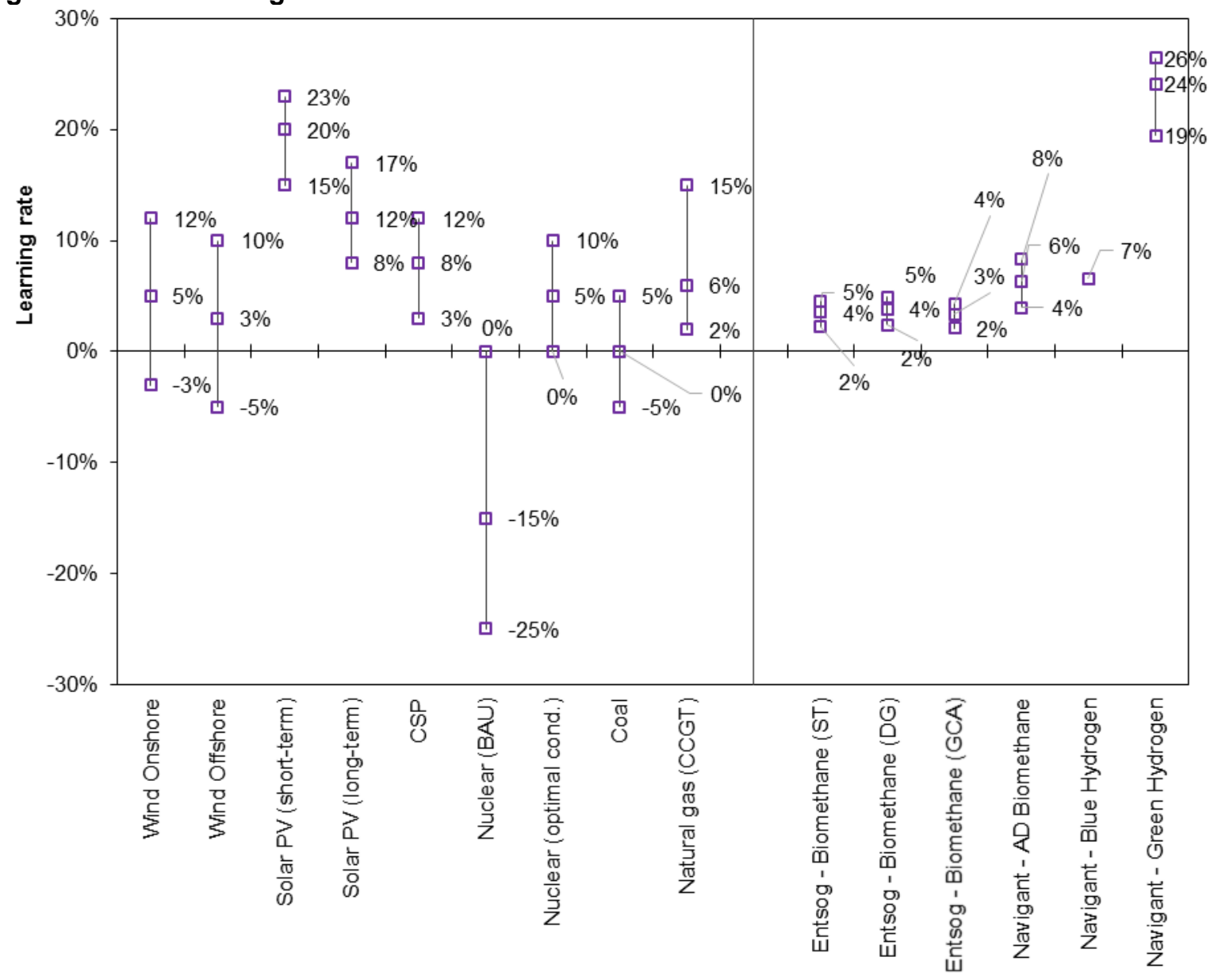

Source: Authors' own calculations for renewable gas production based on cost projections in Figure 12, and productions forecasts in Figure 1 and 2. ST - sustainable transition, DG - distributed generation, GCA - global climate action.

The learning rate for biomethane production based on three scenarios is low (4-5 per cent) as most of the components for biogas upgrade have reached commercial application. By contrast, the learning rate for green hydrogen based on the Navigant projects, in the range 19-26 per cent, is very high and even slightly higher than the historical learning rate for solar PV. Further empirical evidence from additional and larger green hydrogen projects will be required to provide confidence that such an ambitious learning rate can really be achieved. The uncertainties associated with using observed learning rates to anticipate future cost developments are one of the limitations of the experience curve concept. A comparison of the learning curve estimate and actual electricity costs for wind power showed that the learning curve estimate was outside the range of the actual cost in $2004 .{ }^{42}$ Therefore, even though valuable insights are provided from extrapolating cost reductions over long-time frames, caution is required.

\footnotetext{
${ }^{41}$ Samadi, S. (2018). 'The experience curve theory and its application in the field of electricity generation technologies - A literature review'. ScienceDirect, Renewable and Sustainable Energy Reviews, 82, pp.2346-2364.

${ }^{42}$ Ferioli, F., Schoots, K. and van der Zwaan, B. (2009). 'Use and limitations of learning curves for energy technology policy: A component-learning hypothesis'. ScienceDirect, Energy Policy, 37(7) 2525-2535.
} 

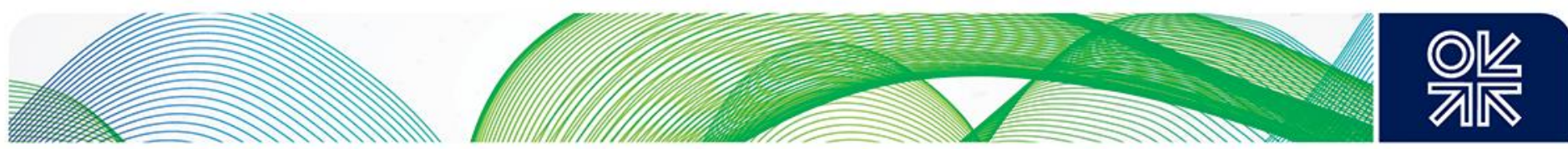

\section{Conclusion: what more is required to be on track for each scenario?}

The objective of this paper has been to analyse the growth rates and cost reductions suggested by various projections of renewable/low-carbon gas production in Europe between 2030 and 2050, and to assess the extent to which actual projects in operation or under development give confidence that such projections may be achievable.

From our analysis, we believe it is important to consider two categories of renewable/low-carbon gas separately: (a) biomethane and (b) renewable gases other than biomethane (notably hydrogen or methane from P2G and hydrogen from methane reforming with $C C S^{43}$ ).

\subsection{Biomethane}

As noted in Section 2, the projections of biomethane production envisage growth from around 20 TWh/year currently to between 200 and 500 TWh in 2040 (as shown in Figure 19). This is very significant growth, but could be achieved with average annual growth rates in the range 5 to 15 per cent per annum. With nearly 500 biomethane plants in operation across Europe, this can be considered mature technology, although some further modest cost savings may be achievable.

Actual future growth will depend on individual investment decisions by project developers which, in turn, is dependent on government policy. However, we noted in Section 3 that average annual growth in biomethane production averaged around 20 per cent per annum between 2013 and 2017. Furthermore we noted that EU growth in solar power generation averaged 41 per cent per annum between 2007 and 2017. We have not been able to identify reliable data for all biomethane plants currently under construction or under development but, provided government policy continues to provide incentives to biomethane producers, it seems reasonable to assume that average annual growth rates in the range 5 to 15 per cent per annum are achievable. The caveat regarding government policy is important, as there is limited scope for further cost reduction of the mature production technology, so costs of biomethane production in the range $€ 40-60 / \mathrm{MWh}$ are likely to remain higher than those of fossil derived natural gas (in the range $€ 10-20 / \mathrm{MWh}$ ). It is assumed that European government policy will continue to strive to achieve an 80 per cent or greater reduction in $\mathrm{CO}_{2}$ emissions from 1990 levels, and thus policies will continue to support production of renewable gases.

\footnotetext{
${ }^{43}$ It could be argued that methane reforming with CCS is not 'renewable', but only 'low carbon' but for convenience we include
} methane reforming with CCS here. 

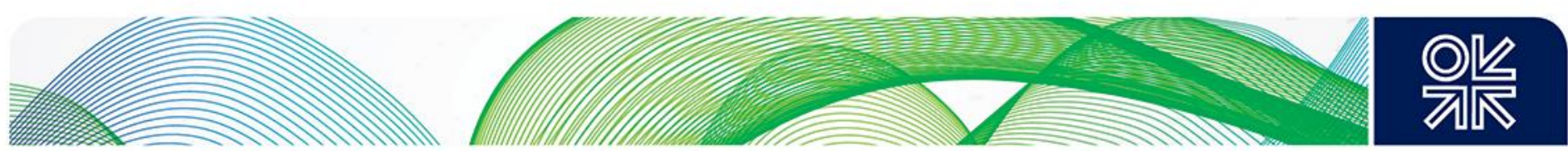

Figure 16: Projections of future biomethane production under various scenarios compared with current production
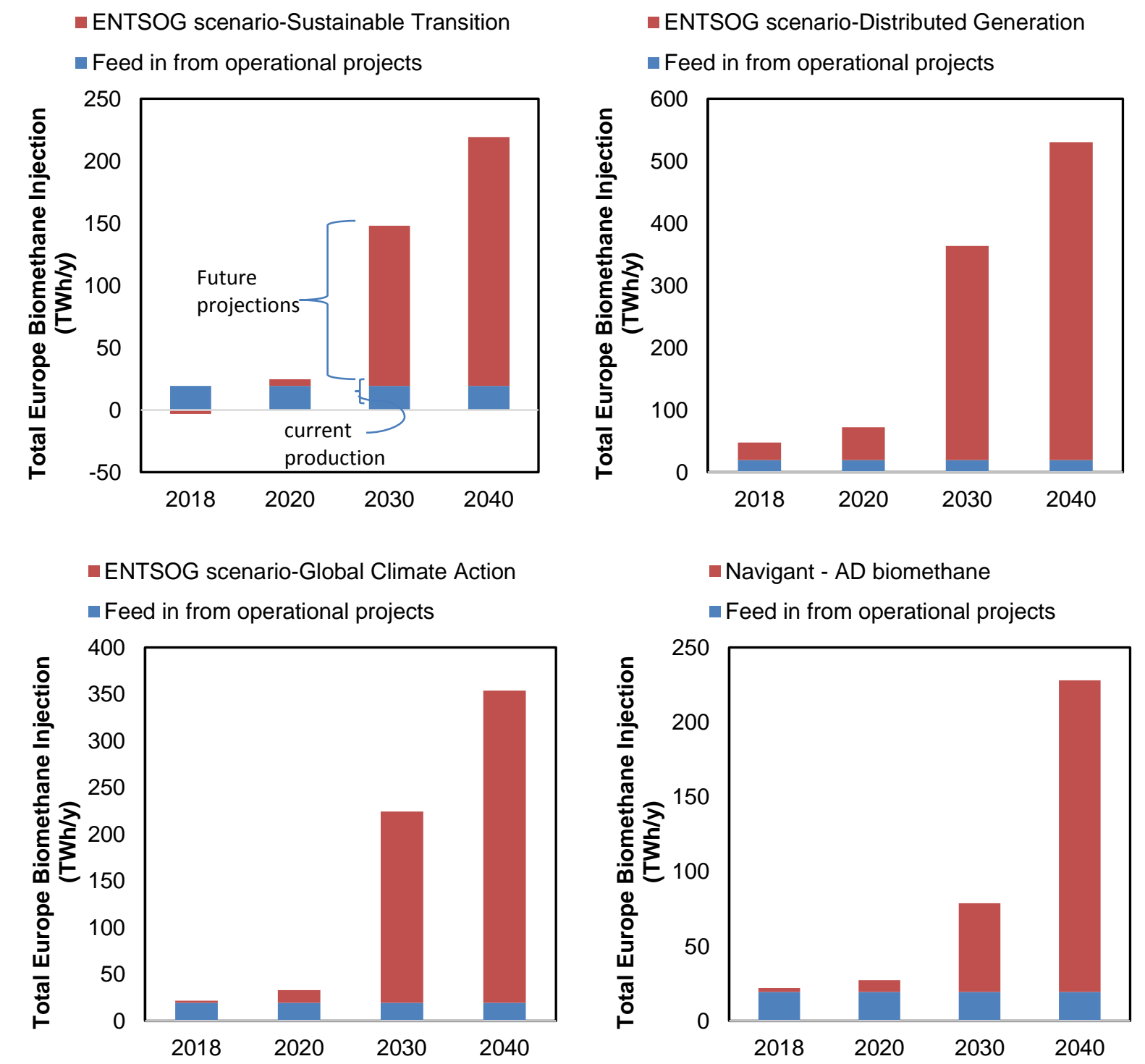

Source: Authors' analysis

\subsection{Renewable gases other than biomethane}

While biomethane technology is relatively mature, technology for production of other renewable gas is in its infancy. Our database contains just 43 renewable hydrogen projects and 15 power to methane projects. Of those, just 10 hydrogen projects and 4 methane projects are currently operational. Total low-carbon hydrogen production capacity is just $0.6 \mathrm{TWh} / \mathrm{year}$, of which more than 90 per cent is represented by the single SMR with carbon capture facility at Port Jerome in France (which some would argue should not be counted as renewable gas production, since the carbon dioxide is still ultimately emitted to the atmosphere). Power to Gas production capacity is less than $50 \mathrm{GWh}(0.05$ TWh). With Entsog targets envisaging between 6 and 14 TWh of P2G production by 2030, there is clearly a very significant scale up challenge. Three P2G projects under development (Hybridge and Element Eins in Germany, and Centurion in the UK) each envisage electrolyser capacity of $100 \mathrm{MW}$, 

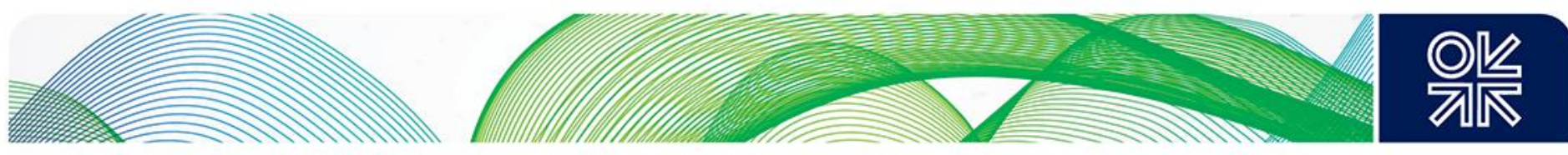

equivalent to potential renewable hydrogen capacity of $500 \mathrm{GWh} / \mathrm{yr}$. These three projects are currently targeting start up around 2022 or 2023 , which, if all were completed as planned would see production capacity of $1.5 \mathrm{TWh} / \mathrm{yr}$ in 2023. Achieving the Entsog target would require between about 10 and 25 similar projects to be on stream by 2030 .

Drawing parallels from the experience with biomethane, with appropriate policy and regulatory support, it should be possible to achieve, or even exceed, this number of projects in a 10 year time scale. We have noted that there are relatively few P2G projects in the feasibility stage. Normal project development experience shows that only a relatively small proportion of projects at the feasibility stage eventually come on stream, so to be on track to achieve the Entsog target we would expect to see at least $20-30$ projects of at least $100 \mathrm{MW}$ electrolyser capacity being actively developed in the next two to three years and additional, larger projects continually entering the 'project funnel'.

Unit cost projections are similarly ambitious. The learning rate for green hydrogen based on the Navigant projects, in the range 19-26 per cent, is very high and even slightly higher than the historical learning rate for solar PV. Further empirical evidence from additional and larger green hydrogen projects will be required to provide confidence that such an ambitious learning rate can really be achieved.

\subsection{Follow up work}

Overall it is clear that collectively the gas industry (across private and public sector companies, regulators and governments) needs to accelerate the level of project activity if there is to be a reasonable chance of meeting stated production targets and unit cost reductions by 2030 and 2050 .

SGI and OIES will both continue their research programmes related to the Future of Gas. For the database in particular, we intend to keep it up to date over the next few years to be able to track the extent to which actual developments are in line with stated aspirations and hence with meeting the ambitions set in Paris in 2015. We envisage that significant renewable gas developments are likely to expand beyond Europe and so will expand the scope of the database accordingly.

We encourage project developers to keep us apprised of new projects and the status of existing ones so that we can ensure that the data is as up to date and comprehensive as possible. 


\section{Appendix. List of names and locations of plants/projects included in SGI/OIES database}

\begin{tabular}{|c|c|c|c|}
\hline \multirow[t]{16}{*}{ Project Name } & \multirow{2}{*}{$\begin{array}{l}\text { Output Type } \\
\text { Biomethane }\end{array}$} & Location & Country \\
\hline & & Asten/Linz & Austria \\
\hline & Biomethane & Bruck an der Leitha & Austria \\
\hline & Biomethane & Engerwitzdorf & Austria \\
\hline & Biomethane & Eugendorf & Austria \\
\hline & Biomethane & Leoben & Austria \\
\hline & Biomethane & Lustenau & Austria \\
\hline & Biomethane & Margarethen am Moos & Austria \\
\hline & Biomethane & Rechnitz & Austria \\
\hline & Biomethane & Schlitters & Austria \\
\hline & Biomethane & Steindorf/Salzburg & Austria \\
\hline & Biomethane & Straß - Leibinitzerfeld & Austria \\
\hline & Biomethane & Vienna Pfaffenau & Austria \\
\hline & Biomethane & Wiener Neustadt & Austria \\
\hline & Biomethane & Zell am See & Austria \\
\hline & Biomethane & Fastranz & Austria \\
\hline NGF Nature Energy Nordfyn A/S & Biomethane & Bogense & Denmark \\
\hline \multirow[t]{2}{*}{ GFE Krogenskær P/S } & Biomethane & Brønderslev & Denmark \\
\hline & Biomethane & Copenhagen Lynetten & Denmark \\
\hline Fredericia Spildevand og Energi A/S & Biomethane & Fredericia & Denmark \\
\hline \multirow{2}{*}{ Vicus B ApS - Frijsenborg Biogas } & Biomethane & Hammel & Denmark \\
\hline & Biomethane & Hashoj / Dalmose & Denmark \\
\hline Hemmet Bioenergi ApS & Biomethane & Hemmet & Denmark \\
\hline AU-vindmøller I/S & Biomethane & Hjerm & Denmark \\
\hline LBT Agro K/S & Biomethane & Hjørring & Denmark \\
\hline BB Biogas ApS & Biomethane & Hjørring & Denmark \\
\hline Rønnovsholm v/N. K. Kirketerp & Biomethane & Hjørring & Denmark \\
\hline NGF Nature Energy Holsted A/S & Biomethane & Holsted & Denmark \\
\hline Horsens Bioenergi ApS & Biomethane & Horsens & Denmark \\
\hline \multirow[t]{2}{*}{ Linkogas A.M.B.A. } & Biomethane & Lintrup & Denmark \\
\hline & Biomethane & Midtfyn & Denmark \\
\hline Rybjerg Biogas I/S & Biomethane & Roslev & Denmark \\
\hline Sindal Biogas v/propr. Per Kirketerp & Biomethane & Sindal & Denmark \\
\hline Madsen Bioenergi I/S & Biomethane & Skive & Denmark \\
\hline Zastrow Bioenergi ApS & Biomethane & Sønders $\varnothing$ & Denmark \\
\hline NGF Nature Energy Vaarst A/S & Biomethane & Vaarst & Denmark \\
\hline Sønderjysk Biogas Bevtoft A/S & Biomethane & Vojens & Denmark \\
\hline \multirow[t]{13}{*}{ Grøngas, Vraa A/S } & Biomethane & Vrå 2 & Denmark \\
\hline & Biomethane & Espoo & Finland \\
\hline & Biomethane & Forssa & Finland \\
\hline & Biomethane & Haukivuori & Finland \\
\hline & Biomethane & Joutsa & Finland \\
\hline & Biomethane & Kouvola & Finland \\
\hline & Biomethane & Lahti & Finland \\
\hline & Biomethane & Laukaa & Finland \\
\hline & Biomethane & Laukaa 2 & Finland \\
\hline & Biomethane & Mustasaari & Finland \\
\hline & Biomethane & Nykarleby/Jeppo & Finland \\
\hline & Biomethane & Riihimaki & Finland \\
\hline & Biomethane & Virolahti & Finland \\
\hline Les Longchamps & Biomethane & Andelnans & France \\
\hline Ecocéa & Biomethane & Chagny & France \\
\hline Gâtinais Biogaz & Biomethane & Château-Renard & France \\
\hline
\end{tabular}



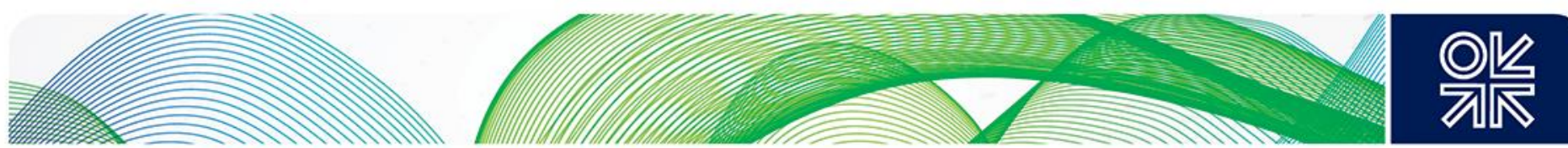

Project Name
Biogaz Meaux
Bioénergie de la Brie
Agrifyl
STEP SILA
Ferme de Chantemerle
Centrale Biogaz du Vermandois
Aquapole
STEP Tour
Champ Fleury
CVO
Bio'Seine

\section{Agribiométhane \\ Quimper-Vol-V \\ ISDND St Florentin}

\section{Méthavos}

Létang Biogaz

Pré du loup énergie

Sioule Biogaz

Biogénère

TVME

Panais Energie

O' Terres Energie

Biovilleneuvois

Biogaz Pévèle

Méthachrist
Output Type

Biomethane

Biomethane

Biomethane

Biomethane

Biomethane

Biomethane

Biomethane

Biomethane

Biomethane

Biomethane

Biomethane

Biomethane

Biomethane

Biomethane

Biomethane

Biomethane

Biomethane

Biomethane

Biomethane

Biomethane

Biomethane

Biomethane

Biomethane

Biomethane

Biomethane

Biomethane

Biomethane

Biomethane

Biomethane

Biomethane

Biomethane

Biomethane

Biomethane

Biomethane

Biomethane

Biomethane

Biomethane

Biomethane

Biomethane

Biomethane

Biomethane

Biomethane

Biomethane

Biomethane

Biomethane

Biomethane

Biomethane

Biomethane

Biomethane

Biomethane

Biomethane

Biomethane
Location

Country

Chauconin

Chaumes-en-Brie

Chaumont

Cran-Gevrier

Epaux-Bezu

Eppeville

Fontanil-Cornillon (Grenoble)

La Riche

Liffré

Lille-Séquedin

Méry-sur-Seine

Morsbach/Forbach

Mortagne-sur-Sèvre

Quimper

Saint-Florentin

Saint-Pourçain-sur-Sioule

Sarreguemines

Sourdun

St Josse-sur-mer

St Pourçain-sur-Sioule

Strasbourg

Symevad Hénin-Beaumont

Ténnelières

Ussy-sur-Marne

Villeneuve-sur-Lot

Wannehain

Woellenheim

Aicha (Osterhofen)

Aiterhofen / Niederbayern

Allendorf-Eder

Altena

Altenhof

Alteno

Altenstadt Schongau

Altenstadt/Hessen

Angermünde

$$
\text { Anklam }
$$

Apensen/Grundoldendorf

Arnschwang

Augsburg

Badeleben

Barby

Barleben

Barsikow

Beerfelde

Beetzendorf

Bergheim/Paffendorf

Berlin-Ruhleben

Blankenhain

Blaufelden - Emmertsbühl

Brandis Waldpolenz

Broistedt
France

France

France

France

France

France

France

France

France

France

France

France

France

France

France

France

France

France

France

France

France

France

France

France

France

France

France

Germany

Germany

Germany

Germany

Germany

Germany

Germany

Germany

Germany

Germany

Germany

Germany

Germany

Germany

Germany

Germany

Germany

Germany

Germany

Germany

Germany

Germany

Germany

Germany

Germany 

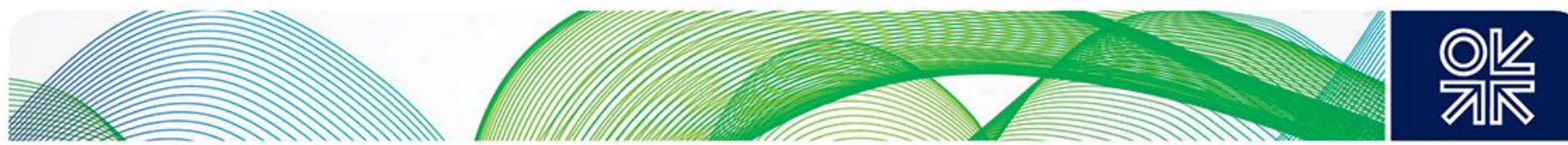

Output Type

Biomethane

Biomethane

Biomethane

Biomethane

Biomethane

Biomethane

Biomethane

Biomethane

Biomethane

Biomethane

Biomethane

Biomethane

Biomethane

Biomethane

Biomethane

Biomethane

Biomethane

Biomethane

Biomethane

Biomethane

Biomethane

Biomethane

Biomethane

Biomethane

Biomethane

Biomethane

Biomethane

Biomethane

Biomethane

Biomethane

Biomethane

Biomethane

Biomethane

Biomethane

Biomethane

Biomethane

Biomethane

Biomethane

Biomethane

Biomethane

Biomethane

Biomethane

Biomethane

Biomethane

Biomethane

Biomethane

Biomethane

Biomethane

Biomethane

Biomethane

Biomethane

Biomethane
Location

Country

Bruchhausen-Vilsen Brumby

Coesfeld / Höven

Dannenberg

Dannheim/Arnstadt/IImenau Dargun

Darmstadt-Wixhausen

Darmstadt-Wixhausen II

Dessau-Roßlau (Zschornewitz?) Dorsten

Drögennindorf

Ebsdorfergrund

Eggertshofen bei Freising

Eggolsheim (Kreis Forchheim)

Eich in Kallmünz

Einbeck

Elsteraue

Eschbach/Breisgau (Heitersheim) Feldberg

Forchheim im Breisgau Forst

Friesoythe (Heinfelde)

Fürth/Seckendorf

Gardelegen

Geislingen

Gellersen (Kirchgellersen)

Genthin

Giesen

Glentorf

Godenstedt

Gollhofen-Ippesheim

Graben/Lechfeld

Grabsleben

Gröbern

Gröden

Groß Kelle / Malchow

Güstrow

Güterglück

Hadmersleben

Hage

Hahnennest

Haldensleben / Ohretal / Satuell

Haldensleben / Ohretal / Satuelle II

Halle/Westfalen

Hamburg

Hankensbüttel / Emmen Hardegsen

Heidenau (Heidkoppel)

Hellerwald / Boppard

Heygendorf

Hohenhameln-Mehrum Holleben
Germany

Germany

Germany

Germany

Germany

Germany

Germany

Germany

Germany

Germany

Germany

Germany

Germany

Germany

Germany

Germany

Germany

Germany

Germany

Germany

Germany

Germany

Germany

Germany

Germany

Germany

Germany

Germany

Germany

Germany

Germany

Germany

Germany

Germany

Germany

Germany

Germany

Germany

Germany

Germany

Germany

Germany

Germany

Germany

Germany

Germany

Germany

Germany

Germany

Germany

Germany

Germany 

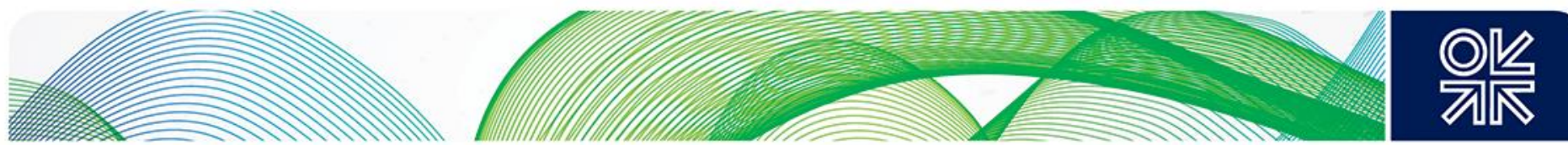

Output Type

Biomethane

Biomethane

Biomethane

Biomethane

Biomethane

Biomethane

Biomethane

Biomethane

Biomethane

Biomethane

Biomethane

Biomethane

Biomethane

Biomethane

Biomethane

Biomethane

Biomethane

Biomethane

Biomethane

Biomethane

Biomethane

Biomethane

Biomethane

Biomethane

Biomethane

Biomethane

Biomethane

Biomethane

Biomethane

Biomethane

Biomethane

Biomethane

Biomethane

Biomethane

Biomethane

Biomethane

Biomethane

Biomethane

Biomethane

Biomethane

Biomethane

Biomethane

Biomethane

Biomethane

Biomethane

Biomethane

Biomethane

Biomethane

Biomethane

Biomethane

Biomethane

Biomethane

Location

Country

Homberg/Efze

Horn - Bad Meinberg

Industriepark Höchst

Jabel / Waren

Jürgenshagen (bei Rostock)

Kannawurf

Karben

Karft

Kerpen

Ketzin

Kirchhain-Stausebach

Kißlegg-Rahmhaus

Klein Schulzendorf / Trebbin

Klein Wanzleben

Kleinlüder bei Fulda

Koblenz

Köckte

Kodersdorf

Könnern 1

Könnern 2

Kroppenstedt

Lambsborn

Laupheim I

Laupheim II

Lehma

Leizen

Lenzen

Leuben

Lichtensee

Lüchow

Lüdershagen / Stralsund

Maihingen

Malstedt

Marienthal

Marktoffingen

Menteroda

Merzig

Müden (Aller)

Mühlacker

Neubrandenburg / Neuhardenberg

Neuburg-Steinhausen

Neukammer 2 (Nauen)

Neuss am Niederrhein

Niederndodeleben I

Niederndodeleben II

Niederröblingen

Nonnendorf

Nordhausen (Bielen)

Oberriexingen

Oebisfelde-Weferlingen

Oebisfelde II

Oschatz (Leuben)
Germany

Germany

Germany

Germany

Germany

Germany

Germany

Germany

Germany

Germany

Germany

Germany

Germany

Germany

Germany

Germany

Germany

Germany

Germany

Germany

Germany

Germany

Germany

Germany

Germany

Germany

Germany

Germany

Germany

Germany

Germany

Germany

Germany

Germany

Germany

Germany

Germany

Germany

Germany

Germany

Germany

Germany

Germany

Germany

Germany

Germany

Germany

Germany

Germany

Germany

Germany

Germany 

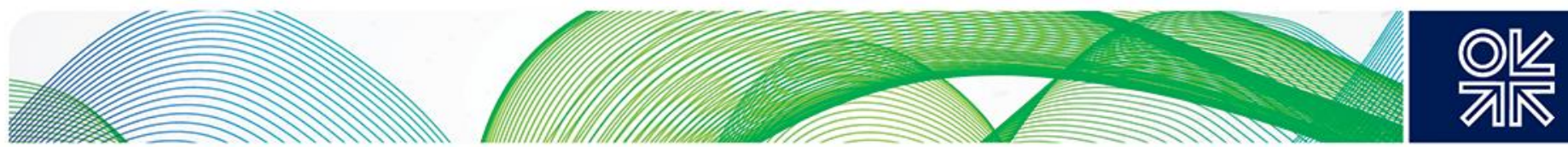

Location

Country

\begin{tabular}{|c|c|c|}
\hline Biomethane & Osterby & Germany \\
\hline Biomethane & Ottersberg & Germany \\
\hline Biomethane & Palmersheim-Euskirchen & Germany \\
\hline Biomethane & Penkun & Germany \\
\hline Biomethane & Pessin & Germany \\
\hline Biomethane & Pirmasens & Germany \\
\hline Biomethane & Platten & Germany \\
\hline Biomethane & Pliening & Germany \\
\hline Biomethane & Pohlsche Heide & Germany \\
\hline Biomethane & itzwalk-Neudorf (Wolfshagen) (Neudorf-Hel & Germany \\
\hline Biomethane & Quesitz / Markransträdt & Germany \\
\hline Biomethane & Rackwitz & Germany \\
\hline Biomethane & Raitzen & Germany \\
\hline Biomethane & Ramstein & Germany \\
\hline Biomethane & Rathenow & Germany \\
\hline Biomethane & Rätzlingen & Germany \\
\hline Biomethane & Reimlingen & Germany \\
\hline Biomethane & Rhede & Germany \\
\hline Biomethane & Riedlingen-Daugendorf & Germany \\
\hline Biomethane & Röblingen am See / Stedten & Germany \\
\hline Biomethane & Ronnenberg & Germany \\
\hline Biomethane & Rosche & Germany \\
\hline Biomethane & Roßwein/Haßlau & Germany \\
\hline Biomethane & Rostock, OT Peez & Germany \\
\hline Biomethane & Sachsendorf & Germany \\
\hline Biomethane & Sagard (Rügen) & Germany \\
\hline Biomethane & Schöllnitz & Germany \\
\hline Biomethane & Schöpstal & Germany \\
\hline Biomethane & Schwandorf & Germany \\
\hline Biomethane & Schwarme & Germany \\
\hline Biomethane & Schwedt & Germany \\
\hline Biomethane & Schwedt II & Germany \\
\hline Biomethane & Schwedt (Neuer Hafen) & Germany \\
\hline Biomethane & Seelow & Germany \\
\hline Biomethane & Semd (Groß Umstadt) & Germany \\
\hline Biomethane & Sinsheim & Germany \\
\hline Biomethane & Staßfurt & Germany \\
\hline Biomethane & Straelen & Germany \\
\hline Biomethane & Stresow & Germany \\
\hline Biomethane & Tangstedt/Bützberg & Germany \\
\hline Biomethane & Thierbach & Germany \\
\hline Biomethane & Tuningen & Germany \\
\hline Biomethane & Uchte & Germany \\
\hline Biomethane & Unsleben & Germany \\
\hline Biomethane & Vehlefanz & Germany \\
\hline Biomethane & Vettin & Germany \\
\hline Biomethane & Vettweiß & Germany \\
\hline Biomethane & Weikersheim & Germany \\
\hline Biomethane & Weißenborn-Lüderode & Germany \\
\hline Biomethane & Werlte & Germany \\
\hline Biomethane & Werlte II & Germany \\
\hline Biomethane & Wetschen & Germany \\
\hline
\end{tabular}



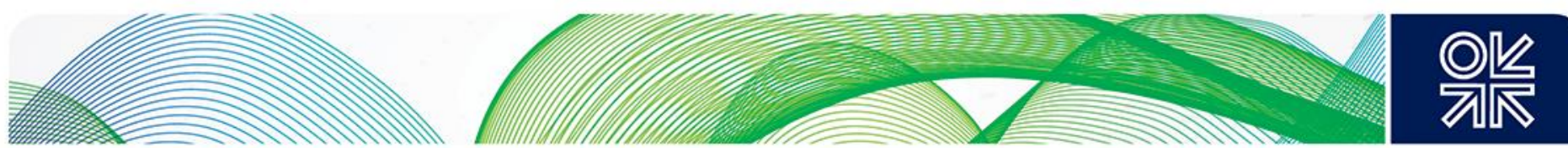

Location

Country

Sugar factory Kaposvar

Sewage plant Zalaegerszeg

Súluvegur

Alfsnes

BAKONA Sàrl

Naturgas Kielen

Minett-Kompost

\begin{tabular}{|c|c|}
\hline Biomethane & Willingshausen/Ransbach \\
\hline Biomethane & Wittenburg \\
\hline Biomethane & Wölfersheim \\
\hline Biomethane & Wolfshagen \\
\hline Biomethane & Wolnzach (Hallertau) \\
\hline Biomethane & Wriezen \\
\hline Biomethane & Wüsting / Hude \\
\hline Biomethane & Zerbst \\
\hline Biomethane & Zeven \\
\hline Biomethane & Zeven II \\
\hline Biomethane & Zittau \\
\hline Biomethane & Zörbig \\
\hline Biomethane & Zülpich \\
\hline Biomethane & Kaposvar \\
\hline Biomethane & Zalaegerszeg \\
\hline Biomethane & Akureyri \\
\hline Biomethane & Reykjavik \\
\hline Biomethane & Este \\
\hline Biomethane & Mantova \\
\hline Biomethane & Montello \\
\hline Biomethane & Ozegna \\
\hline Biomethane & Pinerolo \\
\hline Biomethane & Roma \\
\hline Biomethane & San Giovanni Persiceto \\
\hline Biomethane & Itzig \\
\hline Biomethane & Kielen \\
\hline Biomethane & Mondercange \\
\hline Biomethane & Alphen \\
\hline Biomethane & Beverwijk \\
\hline Biomethane & Biddinghuizen \\
\hline Biomethane & Bunschoten-Spakenburg \\
\hline Biomethane & Collendoorn \\
\hline Biomethane & Den Bommel \\
\hline Biomethane & Dinteloord \\
\hline Biomethane & Eindhoven \\
\hline Biomethane & Groningen \\
\hline Biomethane & Hardenberg \\
\hline Biomethane & Middenmeer \\
\hline Biomethane & Mijdrecht \\
\hline Biomethane & Nuenen \\
\hline Biomethane & Port of Amsterdam \\
\hline Biomethane & Rijsenhout \\
\hline Biomethane & Spaarenwoude \\
\hline Biomethane & Tilburg \\
\hline Biomethane & Tirns \\
\hline Biomethane & Vierverlaten \\
\hline Biomethane & Waalwijk \\
\hline Biomethane & Well \\
\hline Biomethane & Weurt \\
\hline Biomethane & Wijster \\
\hline Biomethane & Wijster 2 \\
\hline Biomethane & Witteveen (Bouwhuis) \\
\hline
\end{tabular}

Germany

Germany

Germany

Germany

Germany

Germany

Germany

Germany

Germany

Germany

Germany

Germany

Germany

Hungary

Hungary

Iceland

Iceland

Italy

Italy

Italy

Italy

Italy

Italy

Italy

Luxembourg

Luxembourg

Luxembourg

Netherlands

Netherlands

Netherlands

Netherlands

Netherlands

Netherlands

Netherlands

Netherlands

Netherlands

Netherlands

Netherlands

Netherlands

Netherlands

Netherlands

Netherlands

Netherlands

Netherlands

Netherlands

Netherlands

Netherlands

Netherlands

Netherlands

Netherlands

Netherlands

Netherlands 

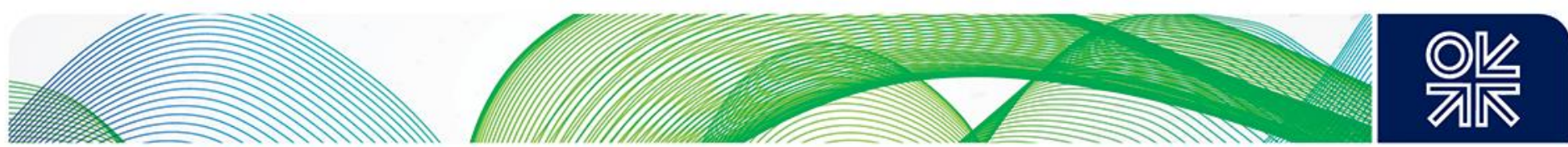

\section{VALDEMINGOMEZ}

Bjuv

Svedjan

Borås 1

Borås 2

Himmerfjärdsverket

Ekeby reningsverk

Ellinge avloppsreningverk

Falkenbergs biogas $A B$

Hulesjöns biogasanläggning

$$
\text { Ekogas }
$$

Göteborg/Arendal

$$
\text { Gotland }
$$

Helsingborg 1 (NSR)

Helsingborg 2 (NSR)

Helsingborg 3 (NSR)

Helsingborg Öresundsverket

gr1

gr2

LP-COOAB

More Biogas

VMAB 1

VMAB 2

Mosserud biogasanläggning

$$
\text { Karlstad }
$$

Katrineholm

SBI Katrineholm AB

Kristianstad 1

Kristianstad 2

Laholm

Käppalaverket

Lidköping

Linköping 2

Luleå Uddebo

Lunds Energi Biogas Källby

Sjölunda

Vadsbo Biogas

Motala

Norrköping

Örebro

Örebro

Gövikens reningsverk

Sävsjö biogas

Skellefteå

Skövde biogas

Södertörn
Biomethane

Biomethane

Biomethane

Biomethane

Biomethane

Biomethane

Biomethane

Biomethane

Biomethane

Biomethane

Biomethane

Biomethane

Biomethane

Biomethane

Biomethane

Biomethane

Biomethane

Biomethane

Biomethane

Biomethane

Biomethane

Biomethane

Biomethane

Biomethane

Biomethane

Biomethane

Biomethane

Biomethane

Biomethane

Biomethane

Biomethane

Biomethane

Biomethane

Biomethane

Biomethane

Biomethane

Biomethane

Biomethane

Biomethane

Biomethane

Biomethane

Biomethane

Biomethane

Biomethane

Biomethane

Biomethane

Biomethane

Biomethane

Biomethane

Biomethane

Biomethane

Biomethane
Zwolle

Lillehammer

Oslo

Oslo/Esval

Stavanger

MADRID

Bjuv

Boden

Borås

Borås 2

Botkyrka

Eskilstuna

Eslöv

Falkenberg

Falköping

Gävle

Göteborg

Gotland

Helsingborg

Helsingborg

Helsingborg

Helsingborg

Jönköping

Jönköping2

Kalmar

Kalmar

Karlshamn

Karlshamn

Karlskoga

Karlstad

Katrineholm

Katrineholm

Kristianstad

Kristianstad 2

Laholm

Lidingö

Lidköping

Linköping

Linköping

Luleå

Lund

Malmö

Mariestad

Motala

Norrköping

Örebro

Örebro 2

Östersund

Sävsjö

Skellefteå

Skövde

Södertörn
Netherlands

Norway

Norway

Norway

Norway

SPAIN

Sweden

Sweden

Sweden

Sweden

Sweden

Sweden

Sweden

Sweden

Sweden

Sweden

Sweden

Sweden

Sweden

Sweden

Sweden

Sweden

Sweden

Sweden

Sweden

Sweden

Sweden

Sweden

Sweden

Sweden

Sweden

Sweden

Sweden

Sweden

Sweden

Sweden

Sweden

Sweden

Sweden

Sweden

Sweden

Sweden

Sweden

Sweden

Sweden

Sweden

Sweden

Sweden

Sweden

Sweden

Sweden

Sweden 

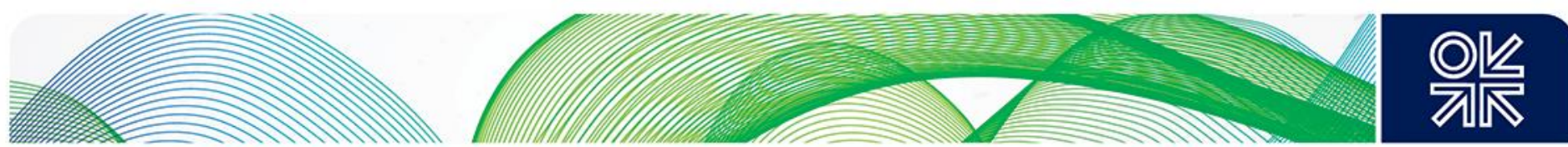

Henriksdal 3

Bromma 1

Bromma 2

Henriksdal 1

Henriksdal 2

Jordberga

Trollhättan 1

Trollhättan 2

Ulricehamn

Uppsala vatten

Uppsala vatten

Biogas Brålanda

VH Biogas

Västerås

SBI Västerås

Lucerna

Reningsverket Sundet Växjö

Zuckerfabrik Aarberg

axpo Kompogas

ARA Bern

ARA Buchs

STEP Penthaz

Emmenbrücke

$$
\text { ARA }
$$

STEP Fribourg

STEP Genève

Swiss Farmer Power

Ecorecyclage

STEP Martigny

ARA Meilen

Biorender

Biopower Pratteln

Grossenbacher

ARA Reinach

Roche

ARA Romanshorn

axpo Kompogas

axpo Kompogas

Association

Axpo-Kompogas Utzenstorf Vétroz

Axpo-Kompogas Volketswil

ARA Wetzikon

Rhy Biogas

ARA Windisch

Axpo-Kompogas Winterthur

ARA Zuchwil

Biogas Zürich

Five Fords WWTW

Ridge Road Farm, Garforth

Faulkners Down Farm

Aspatria Creamery
Biomethane

Biomethane

Biomethane

Biomethane

Biomethane

Biomethane

Biomethane

Biomethane

Biomethane

Biomethane

Biomethane

Biomethane

Biomethane

Biomethane

Biomethane

Biomethane

Biomethane

Biomethane

Biomethane

Biomethane

Biomethane

Biomethane

Biomethane

Biomethane

Biomethane

Biomethane

Biomethane

Biomethane

Biomethane

Biomethane

Biomethane

Biomethane

Biomethane

Biomethane

Biomethane

Biomethane

Biomethane

Biomethane

Biomethane

Biomethane

Biomethane

Biomethane

Biomethane

Biomethane

Biomethane

Biomethane

Biomethane

Biomethane

Biomethane

Biomethane

Biomethane

Biomethane

Stockholm

Stockholm

Stockholm

Stockholm

Stockholm

Trelleborg

Trollhättan

Trollhättan 2

Ulricehamn

Uppsala

Uppsala 2

Vänersborg

Vårgårda

Västerås

Västerås 2

Västervik

Växjö

Aarberg

Bachenbülach

Bern

Buchs

Cossonay

Emmenbrücke

Frauenfeld

Freiburg im Üechtland

Genève

Inwil

Lavigny

Martigny

Meilen

Münchwilen

Pratteln

Reiden

Reinach

Roche

Romanshorn 2

Rümlang

Samstagern

Schönenwerd

Utzenstorf

Vétroz

Volketswil

Wetzikon

Widnau

Windisch

Winterthur

Zuchwil

Zürich

Abenbury, Marchwiel, Wrexham

Aberford - Leeds

Andover - Southampton

Aspatria / Wigton - Cumbria
Sweden

Sweden

Sweden

Sweden

Sweden

Sweden

Sweden

Sweden

Sweden

Sweden

Sweden

Sweden

Sweden

Sweden

Sweden

Sweden

Sweden

Switzerland

Switzerland

Switzerland

Switzerland

Switzerland

Switzerland

Switzerland

Switzerland

Switzerland

Switzerland

Switzerland

Switzerland

Switzerland

Switzerland

Switzerland

Switzerland

Switzerland

Switzerland

Switzerland

Switzerland

Switzerland

Switzerland

Switzerland

Switzerland

Switzerland

Switzerland

Switzerland

Switzerland

Switzerland

Switzerland

Switzerland

United Kingdom

United Kingdom

United Kingdom

United Kingdom 

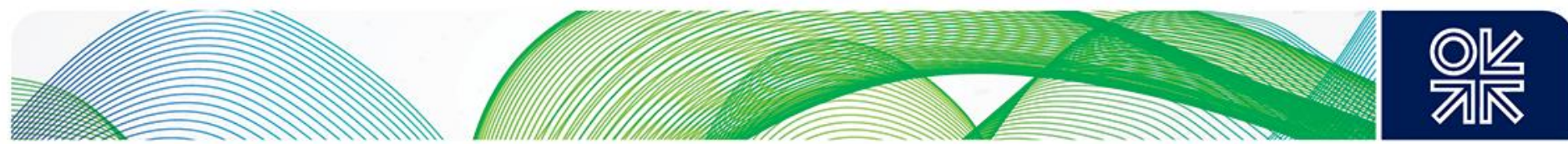

\begin{tabular}{|c|c|c|c|}
\hline Project Name & Output Type & Location & Country \\
\hline Arla Foods Aylesbury Dairy & Biomethane & Aston Clinton -Aylesbury & United Kingdom \\
\hline Strongford Sewage Treatment Works & Biomethane & Barlaston - Staffordshire & United Kingdom \\
\hline North Moor Farm & Biomethane & Belton - East Yorkshire & United Kingdom \\
\hline St Nicholas Court Farm, SNCF & Biomethane & Birchington - Kent & United Kingdom \\
\hline Wingmoor Farm & Biomethane & Bishops Cleeve - Gloucestershire & United Kingdom \\
\hline Downiehills Farm & Biomethane & Blackhills / Peterhead - Aberdeenshire & United Kingdom \\
\hline Manor Farm & Biomethane & Blisworth - Northamptonshire & United Kingdom \\
\hline Manor Farm & Biomethane & Bridgham - Norfolk & United Kingdom \\
\hline Highwood Farm, Brinklow & Biomethane & Brinklow - Warwickshire & United Kingdom \\
\hline Harpham Grange Biogas Plant & Biomethane & Buckton / Bempton - North Yorkshire & United Kingdom \\
\hline East Helscott Farm & Biomethane & Bude - Cornwall & United Kingdom \\
\hline Hollow Road & Biomethane & Bury Saint Edmunds - Suffolk & United Kingdom \\
\hline Cannington Cold Stores Ltd & Biomethane & Cannington - Bridgwater & United Kingdom \\
\hline Mepal/ Chatteris & Biomethane & Chatteris / Ely - Cambridgeshire & United Kingdom \\
\hline Chittering Hollyhouse Farm & Biomethane & Chittering - Cambridge & United Kingdom \\
\hline Enfield Farm & Biomethane & Clyst St Mary - Exester & United Kingdom \\
\hline Former Welbeck Colliery & Biomethane & Cuckney - Nottinghamshire & United Kingdom \\
\hline Energen Biogas Cumbernauld & Biomethane & Cumbernauld - Glasgow & United Kingdom \\
\hline Tornagrain & Biomethane & Dalcross - Morayshire & United Kingdom \\
\hline Derby Island STW Generating Station & Biomethane & Derby - Derbyshire & United Kingdom \\
\hline Glenfiddich Distillery & Biomethane & Dufftown - Keith & United Kingdom \\
\hline Holkham & Biomethane & Egmere - Norfolk & United Kingdom \\
\hline Savock Farm & Biomethane & Ellon - Aberdeenshire & United Kingdom \\
\hline Euston Estates & Biomethane & Euston / Thetford - Suffolk & United Kingdom \\
\hline Raynham Farm & Biomethane & Fakenham - Norfolk & United Kingdom \\
\hline Hill Farm & Biomethane & Farley Hill / Reading - Berkshire & United Kingdom \\
\hline Girvan Distillery & Biomethane & Girvan -Ayrshire & United Kingdom \\
\hline Glenrothes & Biomethane & Glentrothes - Fife & United Kingdom \\
\hline Grindley House Farm & Biomethane & Grindley - Staffordshire & United Kingdom \\
\hline Avonmouth & Biomethane & Hallen / Bristol - Somerset & United Kingdom \\
\hline Court Farm & Biomethane & Hampton Bishop - Hereford & United Kingdom \\
\hline Vulcan Renewables & Biomethane & Hatfield - Doncaster & United Kingdom \\
\hline Hatton Farm & Biomethane & Hatton / Carnoustie - Angus & United Kingdom \\
\hline Blackpits Barn, Helmdon & Biomethane & Helmdon / Brackley - Northamptonshire & United Kingdom \\
\hline Icknield Farm & Biomethane & Ipsden-Oxfordshire & United Kingdom \\
\hline Keithick Farm & Biomethane & Kettins - Blairgowrie & United Kingdom \\
\hline Clapham Lodge/ Leeming Bar & Biomethane & Leeming - North Yorkshire & United Kingdom \\
\hline Springhill Nurseries Ltd - Vale Green Energy & Biomethane & Lower Moor - Pershore & United Kingdom \\
\hline Davyhulme & Biomethane & Manchester - Lancashire & United Kingdom \\
\hline Rainbarrow Farm AD Plant, Poundbury & Biomethane & Martinstown - Dorset & United Kingdom \\
\hline Heath Farm, Sleaford & Biomethane & Metheringham - Lincoln & United Kingdom \\
\hline Methwold & Biomethane & Methwold - Norfolk & United Kingdom \\
\hline Greenlight AD Plant, Teeside & Biomethane & Middlesbrough & United Kingdom \\
\hline Tambowie Farm & Biomethane & Milngavie - Glasgow & United Kingdom \\
\hline Mitcham & Biomethane & Mitcham - Greater London & United Kingdom \\
\hline Howdon STW & Biomethane & Newcastle - Tyne and Wear & United Kingdom \\
\hline Gore Cross & Biomethane & Newport - Isle of Wight & United Kingdom \\
\hline Preston Road AD Plant (Waste AD) & Biomethane & Newton Aycliffe - Durham & United Kingdom \\
\hline Heath Farm & Biomethane & Nocton - Lincoln & United Kingdom \\
\hline Brae of Pert Farm & Biomethane & Northwaterbridge / Laurencekirk - Angus & United Kingdom \\
\hline Crouchland Farm & Biomethane & Plaistow - Billingshurst & United Kingdom \\
\hline Portsdown Hill 2 & Biomethane & Portsdown Hill 2 - Porthsmouth & United Kingdom \\
\hline
\end{tabular}



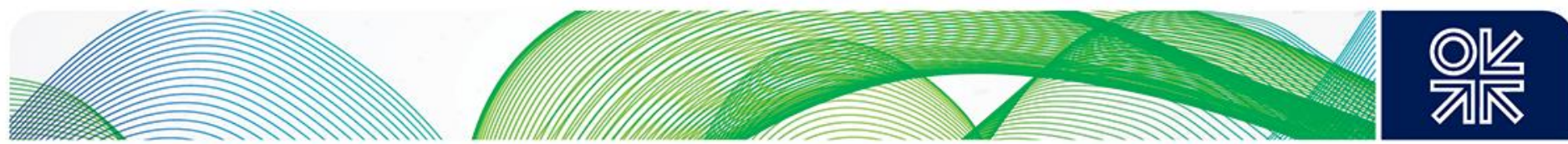

Portsdown Hill 3

Portsdown Hill 4

Portsdown Hill 5

Ebbsfleet Farm

Hibaldstow

Adnams Brewery

Gravel Pit Farm

The Maltings

Great Hele Farm AD farm waste

Frogmary Green Farm

Scampton/Spridlington

Charlesfield Industrial Estate

Penare Farm

Peacehill Farm

Bredbury

Stoke Bardolph energy crop

Stoke Bardolph STW Generating Station

Roundhill STW Generating Station

Minworth Generating Station

Throckmorton - Vale Green 2, Rotherdale Bearley Farm

Penans Farm

Widnes / Granox Biogas Plant

Willand, Cullompton

Sotterly \& Ellough AD plant Bay Farm

Fairfield Farm Energy Limited Wyke Farms Biogas

YO1 4RN

GRHYD

Gaya

Audi Werlte

Gobigas

GrInHy

Helmeth

Windgas Falkenhagen

Windgas Falkenhagen Phase 2

Solothurn Store\&Go

Troia Store\&Go

Exytron Bernsteinsee

Exytron Augsburg

EnergiePark Mainz

BioCat

Refhyne

Ambigo

Don Quichote
Biomethane

Biomethane

Biomethane

Biomethane

Biomethane

Biomethane

Biomethane

Biomethane

Biomethane

Biomethane

Biomethane

Biomethane

Biomethane

Biomethane

Biomethane

Biomethane

Biomethane

Biomethane

Biomethane

Biomethane

Biomethane

Biomethane

Biomethane

Biomethane

Biomethane

Biomethane

Biomethane

Biomethane

Biomethane

Hydrogen

Methane

Methane

Methane

Hydrogen

Methane

Hydrogen

Methane

Methane

Methane

Methane

Methane

Hydrogen

Methane

Hydrogen

Biomethane

Hydrogen
Portsdown Hill 3 - Porthsmouth

Portsdown Hill 4 - Porthsmouth Portsmouth - Southampton Ramsgate - Kent Redbourne - Lincolnshire Reydon - Suffolk Sand Hutton - York

South Milford - North Yorkshire South Molton - Devon

South Petherton - Somerset

Spridlington / Market Rasen - Lincolnshire

St. Boswells - Scottish Borders

St. Columb - Cornwall

St. Fort Estate - Fife

Stockport -Greater Manchester

Stoke Bardolph - Nottinghamshire Stoke Bardolph - Nottinghamshire

Stourbridge - Worcestershire

Sutton, Coldfield - Warwickshire Tilesford - Pershore

Tintinhull / Yeovil - Somerset Truro - Cornwall Widnes / Liverpool

Willand - Cullompton Worlingham - Suffolk Worlington - Suffolk Wormingford - Essex

Wyke Champflower - Bruton York - Norfolk Dunkirk

st Fons, Lyon Werlte

Gotheborg

Salzgitter

Falkenhagen

Falkenhagen

Solothurn

Troia

Bernsteinsee

Augsburg

Mainz

Avedore

Wesseling

Alkmaar

Halle
United Kingdom

United Kingdom

United Kingdom

United Kingdom

United Kingdom

United Kingdom

United Kingdom

United Kingdom

United Kingdom

United Kingdom

United Kingdom

United Kingdom

United Kingdom

United Kingdom

United Kingdom

United Kingdom

United Kingdom

United Kingdom

United Kingdom

United Kingdom

United Kingdom

United Kingdom

United Kingdom

United Kingdom

United Kingdom

United Kingdom

United Kingdom

United Kingdom

United Kingdom

France

France

Germany

Sweden

Germany

Germany

Germany

Germany

Switzerland

Italy

Germany

Germany

Germany

Denmark

Germany

Netherlands

Belgium 

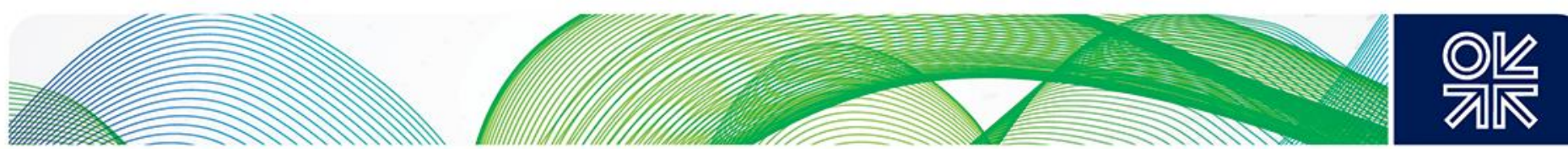

\begin{tabular}{|c|c|c|c|}
\hline Project Name & Output Type & Location & Country \\
\hline Rozenburg & Methane & Rozenburg & Netherlands \\
\hline RWE Power to Gas & Hydrogen & Ibbenburen & Germany \\
\hline $\mathrm{MefCO} 2$ & Hydrogen & Luenen & Germany \\
\hline Hybridge (OGE / Amprion) & Hydrogen & Emsland & Germany \\
\hline Element One (Tennet / Gasunie / Thyssengas & Hydrogen & Lower Saxony & Germany \\
\hline H2Future & Hydrogen & Linz & Austria \\
\hline Underground Sun & Methane & Pilsbach & Austria \\
\hline Wind2hydrogen & Hydrogen & Auersthal & Austria \\
\hline PtG Hungary & Methane & & Hungary \\
\hline Enertrag Windgas & Hydrogen & Prenzlau & Germany \\
\hline RH2 PTG & Hydrogen & Grapsow & Germany \\
\hline Wind to Gas Südermarsch & Hydrogen & Brunsbütel & Germany \\
\hline Hybalance & Hydrogen & Hobro & Denmark \\
\hline Windgas Reitbrook & Hydrogen & Hamburg & Germany \\
\hline HyNet & Hydrogen & & United Kingdom \\
\hline InTEGRel & Hydrogen & Low Thornley & United Kingdom \\
\hline Project Centurion & Hydrogen & Runcorn & United Kingdom \\
\hline $\mathrm{H} 21$ North of England & Hydrogen & & United Kingdom \\
\hline BigHit & Hydrogen & Orkney & United Kingdom \\
\hline THÜGA POWER-TO-GAS PLANT & Hydrogen & Frankfurt & Germany \\
\hline Abalone Energie Nantes (F) & Hydrogen & Nantes & France \\
\hline Fos-sur-Mer (F) - Jupiter 1000 & Hydrogen & Fos-sur-Mer & France \\
\hline Aragon $(E)-$ ITHER & Hydrogen & & Spain \\
\hline Xermade (E) - Sotavento Project & Hydrogen & Xermade & Spain \\
\hline Gasunie/AkzoNobel & Hydrogen & Delfzijl & Netherlands \\
\hline Hystock & Hydrogen & Zuidwending & Netherlands \\
\hline Demo4Grid & Hydrogen & Vols & Austria \\
\hline Port Jerome SMR CCU & Hydrogen & Port Jerome & France \\
\hline HyDeploy & Hydrogen & & United Kingdom \\
\hline $\mathrm{H} 2 \mathrm{~V}$ product for NEL hydrogen & Hydrogen & Notodden & Norway \\
\hline Hydrosol & Hydrogen & Almeria & Spain \\
\hline Surf n Turf & Hydrogen & Orkney & United Kingdom \\
\hline Nouryon (ex AkzoNobel) & Hydrogen & & Netherlands/German! \\
\hline H Vision & Hydrogen & Rotterdam & Netherlands \\
\hline Magnum & Hydrogen & Eemshaven & Netherlands \\
\hline SwissPower Hybridkraftwerk & Methane & Dietikon & Switzerland \\
\hline Energy Park Pirmasens & Methane & Pirmasens & Germany \\
\hline Windgas Hassfurt & Hydrogen & Hassfurt & Germany \\
\hline Haeolus & Hydrogen & Varanger & Norway \\
\hline H2 Aberdeen Hydrogen bus & Hydrogen & Aberdeen & United Kingdom \\
\hline H\&R Oelwerke Schindler & Hydrogen & Hamburg & Germany \\
\hline
\end{tabular}



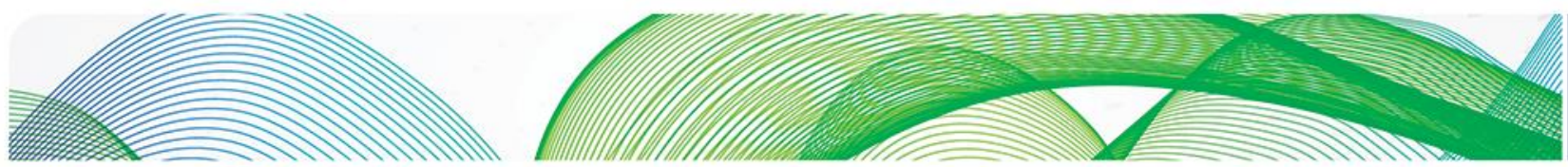

勾先 